\title{
Coseismic and Quaternary Vertical Tectonic Movements, Santo and Malekula Islands, New Hebrides Island Arc
}

\author{
F. W. TAYlor, ${ }^{1,2}$ B. L. Isacks, ${ }^{1}$ C. Jouannic, ${ }^{3}$ \\ A. L. BLOOM, ${ }^{1}$ AND J. DUboIs ${ }^{4}$
}

\begin{abstract}
Emerged late Quaternary coral reefs show that on the $10^{3}$ to $10^{5}$ years time scale the western part of the central New Hebrides arc is divided into several semi-independent uplifted blocks. The blocks are separated by tectonic discontinuities, oriented approximately normal to the arc trend, across which tilt directions or uplift change suddenly. However, none of the blocks is tilted in a direction normal to the arc trend of $\mathrm{N}^{\circ} 0^{\circ} \mathrm{W}$. Two of the discontinuities, across Santo and Malekula Islands, occur near the places where ridges on the north and south flanks of the d'Entrecasteaux fracture zone, a major bathymetric feature on the underthrusting plate, intersect the arc. Each of these tectonic discontinuities approximately coincides with one end of the rupture zone inferred for a shallow thrust-type earthquake sequence in 1965. The discontinuity across Santo also nearly coincides with the south end of the rupture zone inferred for another earthquake sequence in 1973-1974. Uplift of north Malekula, imposed during the 1965 earthquakes, was recorded by emergence of shallow water corals and closely resembles the uplift pattern shown by reef terraces on the $10^{3}$ to $10^{5}$ years time scale. Uplift of south Santo that occurred in recent years, possibly 1965, also resembles the long-term uplift pattern of that island. These observations indicate that the subducting topography of the d'Entrecasteaux fracture zone has controlled segmentation of the central New Hebrides arc both in terms of seismicity on the $10^{1}$ years time scale and deformation on the $10^{5}$ years time scale. Plausible models for buried thrust faults can be made to account for the 1965 uplift pattern. However, there are reasons why a simple elastic dislocation model may be misleading. For example, (1) the uplift data do not adequately constrain the model so that unique fault parameters need be chosen, (2) the block-controlled uplift pattern may interfere with a simple elastic response to faulting, and (3) possible movement on surface faults in north Malekula may have affected the displacement pattern. The upper plate in the Santo-Malekula area might best be viewed as a series of loosely coupled blocks whose movements are dominated by underthrusting of rugged topography on the descending plate. Given the Holocene uplift rates for Malekula and the 1965 example of coseismic uplift, it is possible to consider possible recurrence intervals for earthquakes of the same magnitude and uplift as that of 1965. Many assumptions are inherent in this estimate, but it offers valuable perspective. On Malekula, where there was $1.2 \mathrm{~m}$ of uplift in 1965, the Holocene uplift rate is $3.5 \mathrm{~m} / 1000$ years. Therefore, every 340 years, there must be $1.2 \mathrm{~m}$ of uplift to maintain such an average uplift rate. Interseismic recovery of coseismic uplift could shorten considerably the recurrence interval required to maintain this uplift rate. The convergence rate of $11 \mathrm{~cm} / \mathrm{yr}$ at the New Hebrides arc implies fault slip of $37 \mathrm{~m}$ per 340 years. Since this amount of slip is unlikely for the 1965 earthquakes or their predecessors, either some aseismic slip or a seismic recurrence interval of less than 340 years is suspected.
\end{abstract}

\section{INTRODUCTION}

On August 11, 1965, a sequence of thrusting-type earthquakes beneath the central portion of the New Hebrides island arc was accompanied by uplift of the northern part of Malekula Island. Similar uplift events in arc systems have been relatively rare in historic times, although coseismic uplift is certainly important in the tectonic evolution of many arc systems. The 1965 New Hebrides. earthquake sequence provides an unusual opportunity to study vertical movements associated with a thrusting-type earthquake in an arc system for comparison with similar events in other arc systems.

The relationship between the long-term history of vertical tectonics and coseismic vertical movements in an arc system has been relatively well studied only in Japan [e.g., Ota, 1968; Yoshikawa, 1970; Yonekura, 1972, 1975; Matsuda et al., 1978]. In Shikoku, Japan, emerged marine terraces show the long-

${ }^{1}$ Department of Geological Sciences, Cornell University, Ithaca, New York 14853.

${ }^{2}$ Now at Geophysics Lab of the Marine Science Institute, University of Texas at Austin, Galveston, Texas 77550.

${ }^{3}$ Office de la Recherche Scientifique et Technique, Outre-Mer, Noumea, New Caledonia.

${ }^{4}$ Office de la Recherche Scientifique et Technique, Outre-Mer, 75008 Paris, France.

Copyright (C) 1980 by the American Geophysical Union.

Paper number 80B0812: 5367

0148-0227/80/080B-0812\$01.00 term uplift pattern. Historic records indicate a seismic recurrence interval of about 120 years. Precise leveling before and after the thrusting earthquake of 1946 and other measurements of vertical deformation revealed that only 10 to $20 \%$ of the coseismic vertical deformation is permanent [Fitch and Scholz, 1971].

Vertical displacements associated with the 1960 earthquake in Chile and the 1964 earthquake in Alaska were measured within a few months or years after the earthquakes occurred [Plafker, 1969, 1972; Brown et al., 1977], but details of the longer-term pattern of deformation are poorly known. Emerged marine terraces both in Alaska [Plafker and Rubin, 1978] and in Chile [Kaizuka et al., 1973] have provided some of the most important clues to the long-term history of vertical tectonics.

The New Hebrides arc is one of the rare settings where a coseismic uplift pattern can be measured and compared with a detailed long-term uplift pattern. Because the islands of Santo and Malekula are located extremely close to the main thrust zone and other islands are farther from it, the New Hebrides uplift offers a special opportunity to study upper plate deformation. Coral reefs that grew around the islands have been uplifted to form reef terraces that record long-term Quaternary uplift rates and tilt directions. Much of the surface landscapes of Malekula, Santo, and small neighboring islands

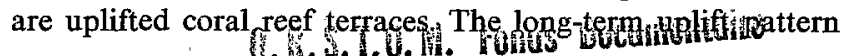




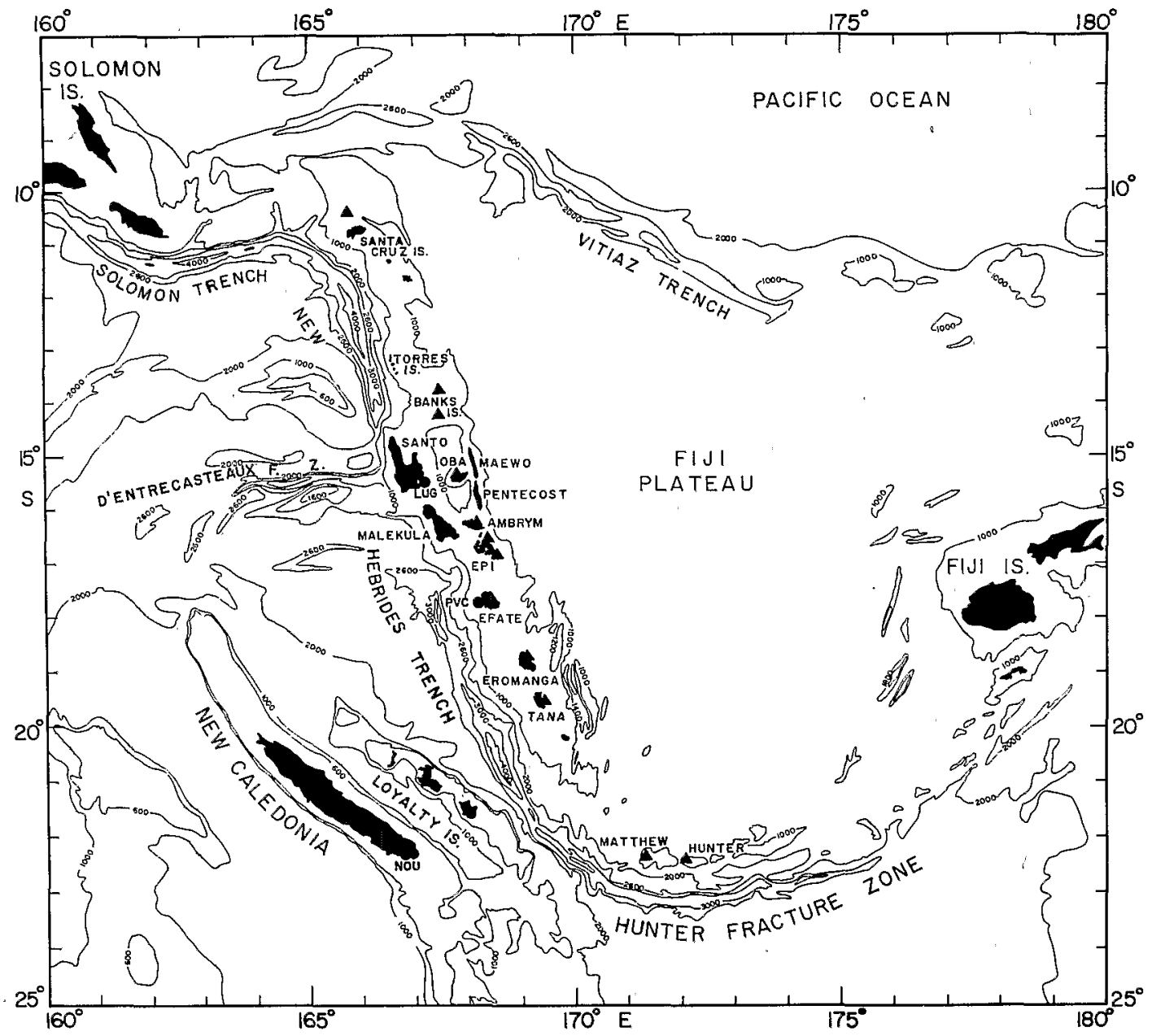

Fig. 1. Bathymetric map of the New Hebrides island arc [after Mammerickx et al., 1971]. Note how the New Hebrides trench is interrupted by the d'Entrecasteaux fracture zone.

and the tectonic discontinuities it reflects are essential to the correct interpretation of the significance of the August 1965 coseismic vertical movements. Comparison of the 1965 and long-term patterns of vertical motions is necessary for evaluation of the frequency of coseismic vertical movements in the New Hebrides island arc. To determine the limits of a region for which a recurrence interval is applicable, the geographic extent of areas that behave as seismotectonic units on both very short and long time scales must be defined. Although the recurrence interval of large thrusting earthquakes in the New Hebrides has not yet been determined, a maximum recurrence interval can now be estimated.

\section{Geologic Setting}

The New Hebrides island arc extends about $1000 \mathrm{~km}$ along a NNW-SSE trend between latitudes $10^{\circ}$ and $22^{\circ} \mathrm{S}$ from the Solomon arc in the north to the Matthew-Hunter ridge in the south (Figure 1). At the New Hebrides trench the Indian-Australian plate is being subducted beneath the Pacific plate at about $11 \mathrm{~cm} /$ yr [Dubois et al., 1977]. The convergence direction averaged from focal mechanisms is $N 75^{\circ} \mathrm{E} \pm 11^{\circ}[$ Pascal et al., 1978] or almost perpendicular to the arc trend of $\mathrm{N} 20^{\circ} \mathrm{W}$. Arc-polarity reversal is believed to have resulted in the present arc geometry with subduction of the Indian-Australian plate initiated at the New Hebrides arc in the late Pliocene [Falvey, 1978] or earlier [Chase, 1971; Mitchell and Warden, 1971; Karig and Mammerickx, 1972]. Both Santo and Malekula on the west and Maewo and Pentecost on the east side of the Aoba basin have been strongly uplifted in the Qua- ternary [Mitchell and Warden, 1971; Luyendyk et al., 1974] (Figure 2).

Between latitudes $14^{\circ}$ and $18^{\circ} \mathrm{S}$, just west of Santo and Malekula, there is no trench. Here, the d'Entrecasteaux fracture zone, expressed as a ridge on the Indian-Australian plate, intersects the arc (Figure 2). Thus the New Hebrides trench consists of northern and southern segments. If the two trenches are connected by a straight line, the line lies just off the west coast of Malekula and adjacent to the extreme western coast of Santo (Figure 2). The westernmost parts of Santo and Malekula therefore are in an anomalous position approximately where the inner trench slope is normally located. Santo and Malekula may have moved westward as the Aoba basin opened in post-Miocene time [Karig and Mammerickx, 1972; Luyendyk et al., 1974]. Alternatively, the anomalous positions of Santo and Malekula may be related to subduction of the d'Entrecasteaux fracture zone [Ravenne et al., 1977; Chung and Kanamori, 1978a,b]. The results reported in our paper indicate that subduction of the d'Entrecasteaux fracture zone plays an important role in determining the pattern of Quaternary vertical movements. These movements, however, may not account for all of the anomalous topography of islands in the central region. The effects of vertical movements may be merely superimposed upon the rifted intra-arc morphology of late Miocene or Pliocene age.

Focal mechanisms and earthquake locations near Santo and Malekula indicate no important change in seismicity along the arc near these islands. The underthrusting lithosphere beneath Santo and Malekula is continuous with that to 


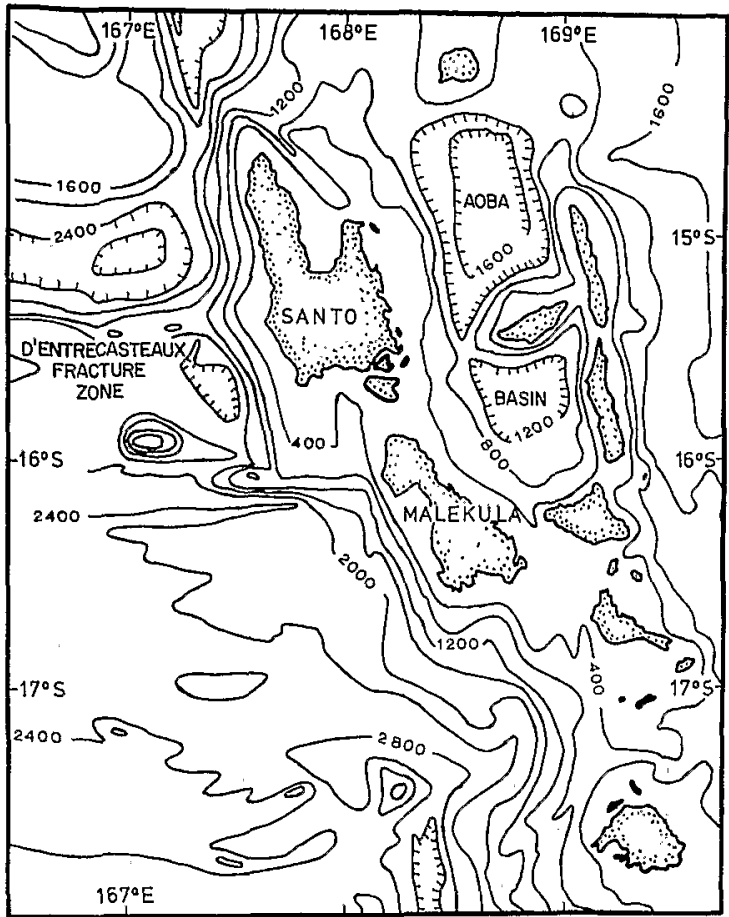

Fig. 2. Bathymetric map of the central New Hebrides (contour interval $=400$ fathoms; after Mammerickx et al. [1971]). Note the lack of a trench immediately west of Santo and Malekula. A line connecting the ends of the trenches seen at the top and bottom of the figure would pass along the west coast of Santo.

the north and south. The geometry of the subducted lithosphere is relatively uniform throughout the arc [Pascal et al., 1978].

Both Santo and Malekula are dominated by high-angle block faults [Mitchell and Warden, 1971; Mallick, 1973; Mallick and Greenbaum, 1977]. On western Santo, faults separate eastwardly tilted blocks that step down from west to east [Robinson, 1969]. However, the west coast of Santo is probably controlled by a major fault system that is downthrown to the west [Mallick and Greenbaum, 1977]. These faults imply that total uplift increases from east to west across the eastwardly tilted fault blocks. But near the west coast, the trend suddenly reverses and total uplift decreases dramatically across one or more faults controlling the west coast.

Northwest trending faults on Malekula appear to control the morphology of much of the coast and commonly displace Quaternary coral reef terraces. On northwestern Malekula the closely spaced faults are reportedly downthrown to the east and cut the reef terraces and underlying sedimentary rocks into southwest dipping blocks [Mitchell, 1971, p. 31]. However, the geomorphology of northwest Malekula indicates that some major faults are downthrown to the west.

\section{TECTONIC History ON THE $10^{3}$ TO $10^{5}$ YeAR TIME SCALE}

The uplifted reef terraces that cap Malekula and Santo offer a long-term $\left(10^{3}\right.$ to $10^{5}$ years) record of the uplift and tilting of these islands [Jouannic et al., 1980]. The uplifted reefs are being mapped from aerial photographs and field observations. Three main processes interacted to form and determine the characteristics of the reef terraces: (1) Glacioeustatic sea level fluctuations, (2) tectonic uplift, and (3) coral reef growth and development. Each reef terrace represents a former sea level surface that has been uplifted and deformed. Radiometric dating of fossil corals from the terraces allows calcu- lation of average uplift rates for many points on each island and thus an absolute chronology of uplift and deformation through time. Even without a detailed absolute chronology, reef terraces record the pattern of tilting and deformation. The principles of reef terrace formation on rising coasts were established on islands such as Barbados [e.g., Mesolella et al., 1969] and New Guinea [Bloom et al., 1974; Chappell, 1974]

\section{Malekula}

Most of north Malekula is capped by coral limestone (Figure 3) that can be resolved into a sequence of up to nine reef terraces [Mitchell, 1968, 1971; Jouannic et al., 1980]. Radiometric dates on fossil corals indicate that emerged coastal terraces fringing nearly all of north Malekula are Holocene in age (samples M-A-1, M-X-2, and M-Y-2; Table 1). In general, each of the terraces increases in altitude from the northeast toward the southwest coast of north Malekula. On the basis of the altitudes and dates for the Holocene terrace complex, uplift rates range from $0.3 \mathrm{~mm} / \mathrm{yr}(\mathrm{M}-\mathrm{X}-2$; Table 1) to at least $3.5 \mathrm{~mm} / \mathrm{yr}(\mathrm{M}-\mathrm{Y}-2$; Table 1$)$ from northeast to southwest across north Malekula.

To determine the direction of tilting recorded by the older uplifted terraces, three-point geometric problems were solved for segments of four different reef terraces that can be traced for long distances on north Malekula (Figure 4). Some of the terrace segments are displaced by faults that probably affect the amount and direction of tilt to a small extent. However, the three tilt solutions shown are remarkably consistent and indicate tilt directions of $\mathrm{N} 42^{\circ} \mathrm{E}, \mathrm{N} 44^{\circ} \mathrm{E}$, and $\mathrm{N} 51^{\circ} \mathrm{E}$ (Figure 4). Two other solutions, not shown, gave tilt directions of $\mathrm{N} 39^{\circ} \mathrm{E}$ and $\mathrm{N} 51^{\circ} \mathrm{E}$. The average of these five tilt determinations is $\mathrm{N} 45^{\circ} \mathrm{E} \pm 5^{\circ}$. The tilt of these terraces ranges from

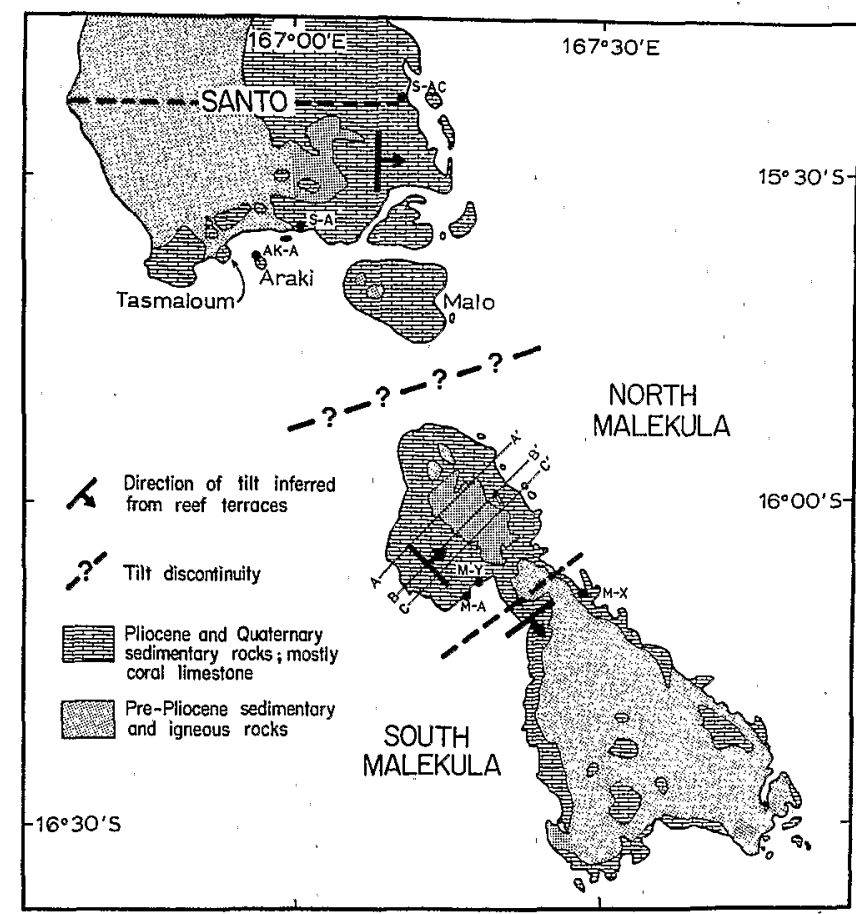

Fig. 3. Geologic map of southern Santo and Malekula [after Mitchell, 1966; 1971; Mallick and Greenbaum, 1977]. This figure shows the distribution of relatively young coral limestones and related sedimentary rocks and the older pre-Pliocene rocks. Tilt directions for southern Santo, north Malekula, and south Malekula are indicated by strike and dip symbols. The solid circles mark localities from which corals were collected for radiometric dating (Table 1 ). The lines $A-A^{\prime}$,

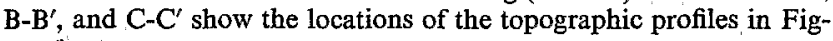
ure 5 . 
TABLE 1. Radiocarbon Dates

\begin{tabular}{|c|c|c|c|c|c|c|c|c|}
\hline \multirow{2}{*}{$\begin{array}{c}\text { Field } \\
\text { Sample }\end{array}$} & \multirow[b]{2}{*}{ Lab* } & \multirow{2}{*}{$\begin{array}{c}\text { Coral } \\
\text { sp. }\end{array}$} & \multicolumn{3}{|c|}{ 230-Th/234-U Dates } & \multirow{2}{*}{$\begin{array}{c}\text { Age, } \\
\text { years B.P. }\end{array}$} & \multirow{2}{*}{$\begin{array}{c}\text { Altitude } \\
\text { of } \\
\text { Sample } \dagger, m\end{array}$} & \multirow{2}{*}{$\begin{array}{l}\text { Altitude } \\
\text { of } \\
\text { Terracef, } n\end{array}$} \\
\hline & & & Total U, ppm & 234-U/238-U & $230-\mathrm{Th} / 234-\mathrm{U}$ & & & \\
\hline AK-A-1 & $F$ & Acropora & & & & $5470 \pm 160$ & 28 & 28 \\
\hline M-A-8 & $\mathbf{F}$ & Porites & & & & $2530 \pm 100$ & 4.2 & 15.5 \\
\hline $\mathrm{M}-\mathrm{X}-2$ & $\mathrm{~F}$ & Platygyra & & & & $2970 \pm 200$ & 1 & - \\
\hline S-AC-1 & LD & Porites & & & & $5940 \pm 190$ & 8 & 8 \\
\hline$M-Y-2$ & LD & Favia & $2.64 \pm 0.07$ & $1.13 \pm 0.02$ & $0.050 \pm 0.004$ & $5600 \pm 500$ & 15.3 & 19.5 \\
\hline S-AC-1 & LD & Porites & $2.73 \pm 0.05$ & $1.14 \pm 0.02$ & $0.051 \pm 0.004$ & $5700 \pm 500$ & 8 & 8 \\
\hline S-A-I & LD & Oulophyllia & $2.52 \pm 0.07$ & $1.12 \pm 0.03$ & $0.045 \pm 0.005$ & $5000 \pm 600$ & 15.5 & 21.5 \\
\hline
\end{tabular}

${ }^{*} \mathrm{LD}=$ W. S. Broecker, Lamont-Doherty Geological Observatory, Palisades, New York; F = J.-C. Fontes, Laboratoire d'Hydrologie et de Geochimie Isotopique, Universite de Paris-Sud, Orsay, France.

†All altitude measurements are from the highest living corals or, alternatively, low-tide level.

$0.27^{\circ}$ to $2.13^{\circ}$ and increases from lower to higher (younger to older) terraces.

The average direction of tilting shown by the reef terraces on north Malekula $\left(\mathrm{N} 45^{\circ} \mathrm{E}\right)$ is supported by other observations. For example, the eastern coast of Malekula is nearly straight and trends almost exactly NW-SE, perpendicular to the direction of tilting determined from the terraces. Either the eastern coast is controlled by a major fault, or it is a result of very consistent tilting to the northeast. In either case the trend of the northeast coast is probably related to the NE tilt direction. Topographic profiles oriented NE-SW on north Malekula confirm a history of tilting toward the NE and that the greatest total uplift probably has been in the western part of north Malekula (Figure 5).

Southwest of the axis of maximum uplift on north Malekula is a zone of parallel NW-SE trending faults that separate fault blocks stepping down to the west coast (Figures 4 and 5).

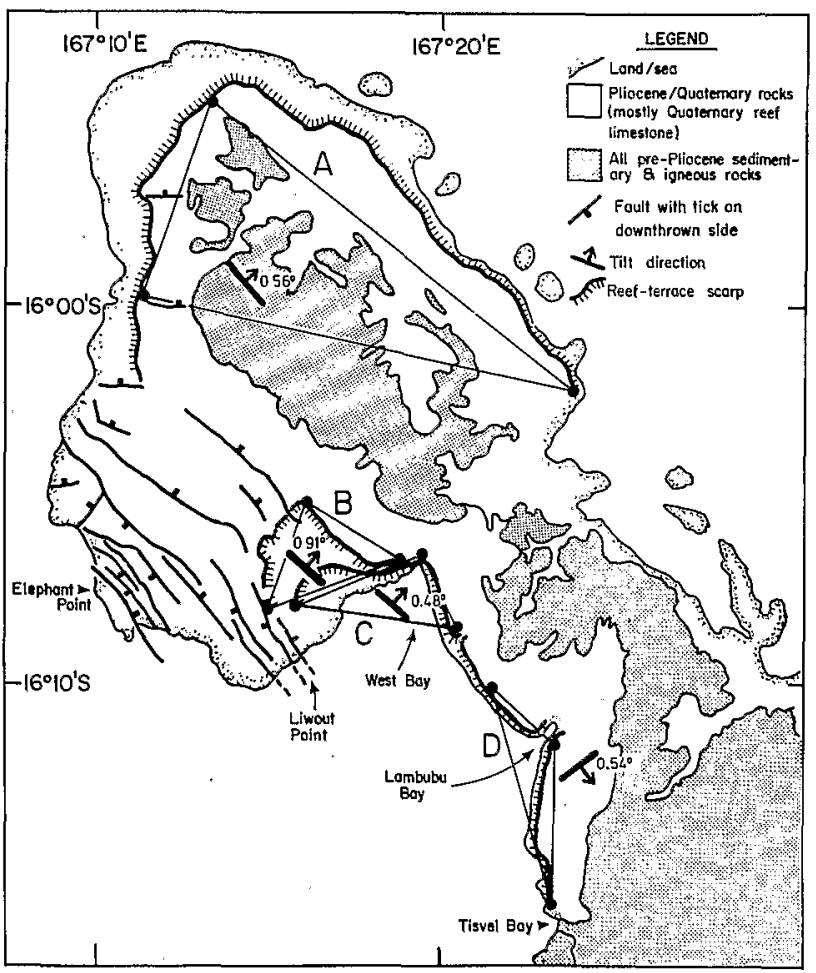

Fig. 4. Reef terraces used to determine the long-term tilt directions for Malekula. Only a few of the faults in western north Malekula are shown. The tilt directions indicated by each geometric solution are: $\mathrm{A}=\mathrm{N} 39^{\circ} \mathrm{E}, \mathrm{B}=\mathrm{N} 44^{\circ} \mathrm{E}, \mathrm{C}=\mathrm{N} 42^{\circ} \mathrm{E}$, and $\mathrm{D}=\mathrm{N} 143^{\circ} \mathrm{E}$. The amount of tilt for each triangle is indicated next to the tilt symbol of the figure.
Some of these faults extend from the interior of north Malekula to the coast, where they offset the modern reef and presumably continue offshore. Offshore to the southwest of the NW-SE faults may be additional submarine faults and fault blocks parallel to those on land. Southwest from the axis of maximum uplift, the major fault blocks are downthrown to the southwest (Figures 4 and 5). However, many of the minor fault blocks are upthrown on the southwest sides of faults. This variability in faulting makes it difficult to propose an adequate model to account for the faults. The reef terraces indicate that all of the fault blocks have been uplifted but at decreasing rates away from the NW-SE axis of maximum uplift. Thus there is a narrow strip of land along the southwest coast of north Malekula that has undergone net tilting toward the southwest.

Movements on the NW-SE faults in north Malekula must have influenced the long-term uplift pattern. Indeed, the uplift pattern imposed during the 1965 earthquakes may have been significantly affected by slip on one or more of these faults. For example, at Liwout Point (Figure 4) a fault displaces the youngest of three Holocene terraces by about $2 \mathrm{~m}$, although there is no evidence that this fault slipped in 1965. The oldest radiometric date from the youngest displaced terrace is $2530 \pm 100$ B.P. (M-A-8; Table 1). Either there has been $0.8 \mathrm{~m} / 1000$ years of displacement on this fault in the past 2500 years or more rapid displacement during a shorter interval.

In contrast to north Malekula, only a small portion of south Malekula, mainly that adjacent to the coast, is capped by coral limestone (Figures 3 and 4). The interior limestone plateaus may include some coral limestone but are mainly nonreef limestones [Mitchell, 1966]. Three reef terraces can be traced along the west coast from north Malekula for about 10 $\mathrm{km}$ into south Malekula. The altitudes of these terraces decrease from north into south Malekula. Except for the Holocene reef, only isolated segments of reef terraces appear on air photographs of most of south Malekula. The clear implication is that, in general, late Quaternary uplift rates have been slower in south than in north Malekula. However, some of the coast of south Malekula has not yet been investigated. Possibly, some areas there will prove to have uplift rates comparable to those of north Malekula.

A late Quaternary terrace that can be traced along the west coast from West Bay in north Malekula into south Malekula was used for a three-point tilt solution (Figure 4). Southeastward from West Bay, its altitude increases slightly to a maximum of about $140 \mathrm{~m}$ midway between West Bay and Lambubu Bay, then decreases rapidly to about $80 \mathrm{~m}$ at Lambubu Bay. Southward from Lambubu Bay, the terrace gradu- 


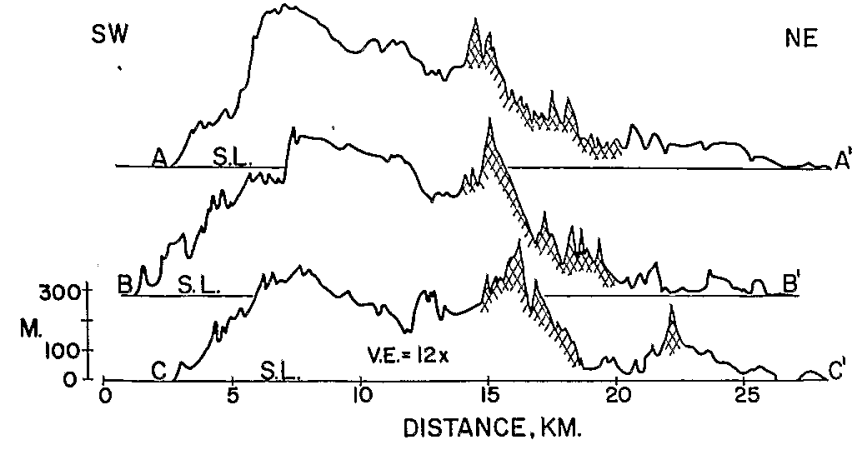

Fig. 5. Topographic profiles oriented NE-SW across north Malekula. Profile locations are shown on Figure 3. The cross-hatched pattern indicates where each profile crosses outcrops of pre-Pliocene rocks. The southwestward sloping left end of each profile crosses an area cut by closely spaced NW-SE trending faults. The overall tilt of north Malekula indicated by the profiles is $1.72^{\circ}$ if one assumes that Malekula began as flat seafloor that was subsequently uplifted and deformed.

ally decreases in altitude to about $20 \mathrm{~m}$ near Tisvel Bay but cannot be traced farther south. The three-point solution for this terrace gives a tilt direction of $\mathrm{N} 143^{\circ} \mathrm{E}$ for this part of south Malekula. On north Malekula the same terrace gives a tilt solution of $\mathrm{N} 42^{\circ} \mathrm{E}$ (Figure 4). Although the altitude control for this terrace is relatively poor, its tilt directions are clearly different on north and south Malekula. The sudden change of terrace altitude marks a sharp tilt discontinuity separating north and south Malekula.

Across the neck of central Malekula, a prominent ridge of pre-Pliocene rocks coincides with the tilt discontinuity and forms a drainage divide (Figures 3 and 4). On the north side of the ridge, streams flow toward the northeast, but on the south side, streams flow southward and converge on Lambubu Bay. The reef terraces indicate that local uplift rates are greater where terraces cross the tilt discontinuity. Rapid local uplift along the tilt discontinuity may explain the ridge and drainage divide.

The tilt discontinuity across central Malekula is expressed on the east coast as a subtle change in coastal geomorphology, probably because uplift rates decrease rapidly from north to south across the discontinuity. The emerged Holocene reef on the east coast loses altitude from NW to SE. This altitude loss is seen from the air as the disappearance of a conspicuous emerged Holocene reef terrace south of the tilt discontinuity. The northernmost occurrence of mangrove also nearly coincides with the northeast end of the tilt discontinuity on the northeast coast. Mangrove requires the wide intertidal zone characteristic of south Malekula in contrast to the narrow rocky intertidal zone of the more rapidly uplifting coast of north Malekula.

\section{Santo and Neighboring Isles}

Nearly all of the eastern plateau region of Santo is capped by coral reef limestone, in contrast to most of the western half of the island, where older rocks crop out and where there are only local patches of overlying coral limestone along the coast (Figure 3). Fossil corals from a coastal terrace complex bordering all of eastern Santo and several small neighboring islands give radiometric dates that fall within the Holocene epoch (Table 1) Jouannic et al. [1980]). The maximum altitude of the Holocene terrace complex ranges from $8 \mathrm{~m}$ above the living reef on southeastern Santo (S-AC; Table 1) to $21.5 \mathrm{~m}$ on the central southern coast of Santo (S-A; Table 1) to $28 \mathrm{~m}$ a little farther west off the south coast of Santo on the island of Araki (AK-A in Table 1). The elevations and ages of the Holocene terraces indicate an average uplift rate that increases from about $1 \mathrm{~mm} / \mathrm{yr}$ in the extreme eastern part of Santo to at least $5 \mathrm{~mm} / \mathrm{yr}$ in the central western part of south Santo. Neef and Veeh [1977] obtained radiometric dates from Malo Island, close to Santo's southeastern coast, that are consistent with these uplift values. A three-point geometric tilt solution for a reef terrace on Malo indicates a tilt of $0.20^{\circ}$ toward $\mathrm{N} 96^{\circ} \mathrm{E}$, but because of the $40-\mathrm{m}$ contour interval of the map from which we derived these altitudes, altitude estimates are not extremely accurate. This E or ESE tilt direction is consistent with the conclusions of Mallick and Greenbaum [1977], who reported an ESE direction of tilting for both southeastern Santo and Malo.

There is evidence that a major tectonic feature crosses Santo in an E-W direction where a ridge on the north flank of the d'Entrecasteaux fracture zone intersects the arc (Figure 2). At the intersection, near latitude $15^{\circ} 25^{\prime} \mathrm{S}$, there is a westward bulge in the west coast of Santo. Directly inland to the east are the highest mountains on Santo (e.g. Mount Tabwemesana $=1879 \mathrm{~m}$; Mount Vulai $=1747 \mathrm{~m}$; Mount Teremaratsa $=1593 \mathrm{~m}$ ). Slightly south of the intersection are other high peaks (e.g., Peak Santo $=1704 \mathrm{~m}$; Mount Balitsololo $=1671$ $\mathrm{m})$. At the northern edge of the area of intersection is a major E-W fault, north of which the exposed rocks are much

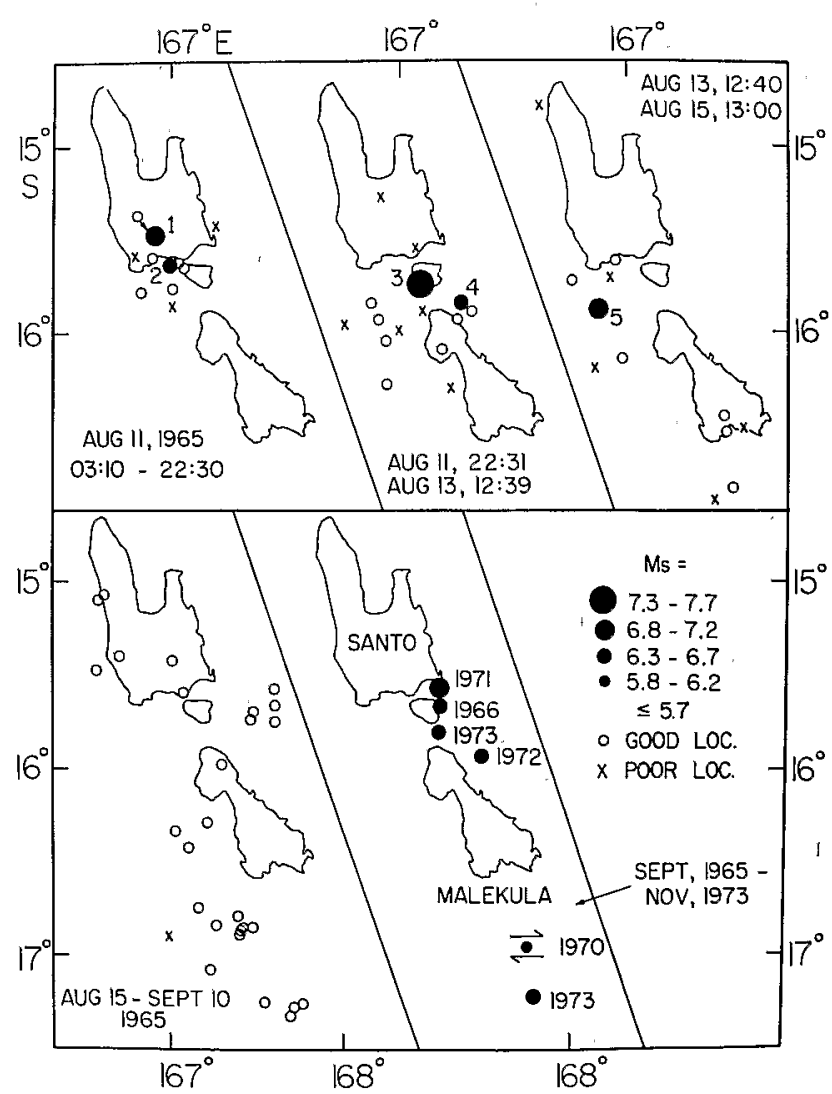

Fig. 6. The earthquake sequence associated with uplift of northern Malekula in August 1965. The foreshock-mainshock-aftershock sequence in the top panels indicates that the rupture began under Santo and migrated southward beneath Malekula. Note that the early aftershocks (top center and right) tend to lie between Santo and central Malekula but that later aftershocks (lower, left) tend to be more around than within the zone of early aftershocks. 


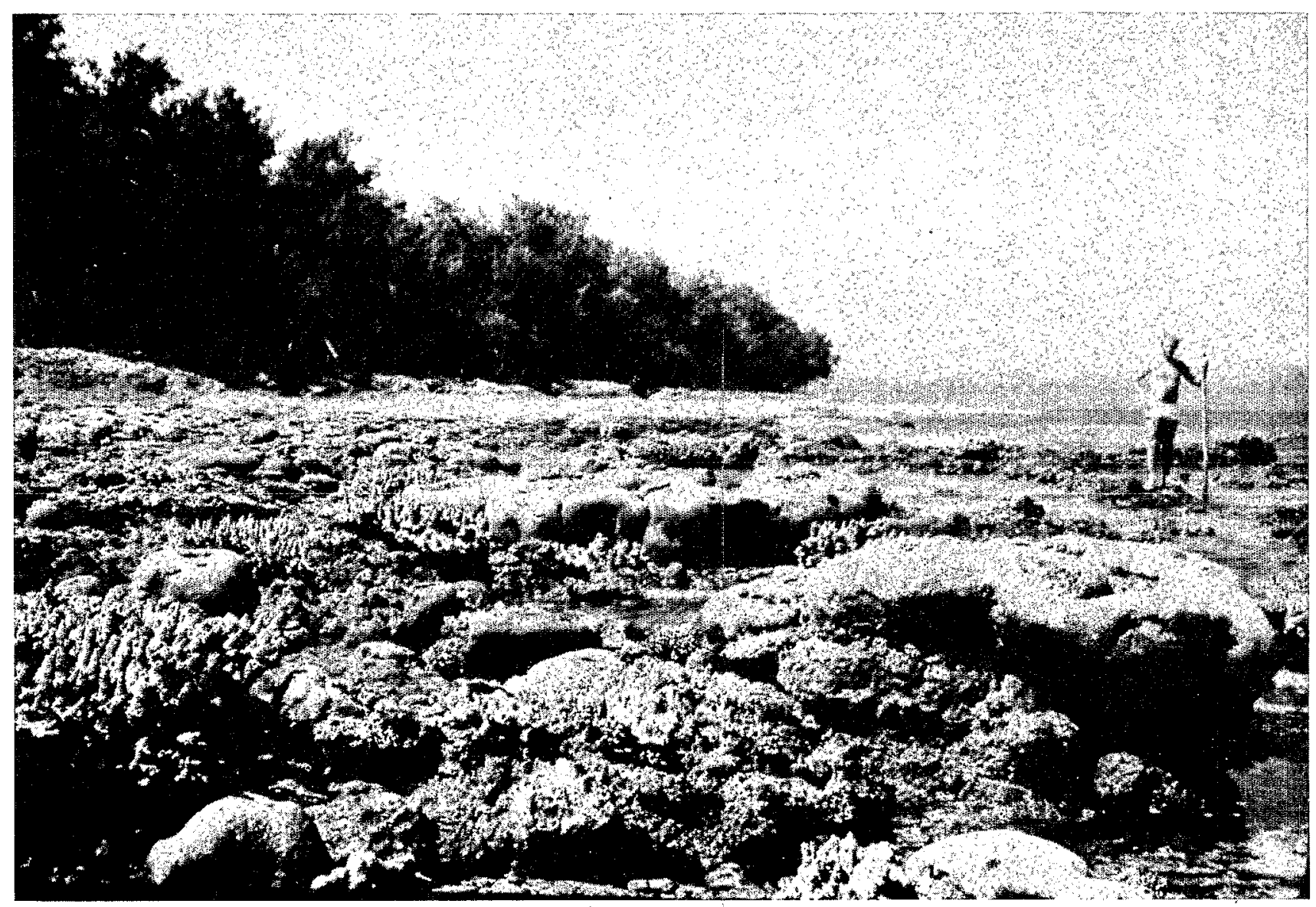

Fig. 7. Photograph of the corals killed by uplift in August 1965 at Liwout Point (station $\mathrm{h}$ on Figure 8). Here, $0.79 \mathrm{~m}$ of $1965^{\prime}$ uplift was measured.

younger [ Mallick and Greenbaum, 1977; Macfarlane, 1977]. North of the fault, maximum altitudes are several hundred meters less than to the south. This possible tectonic boundary has not been defined as a tilt discontinuity, but studies in

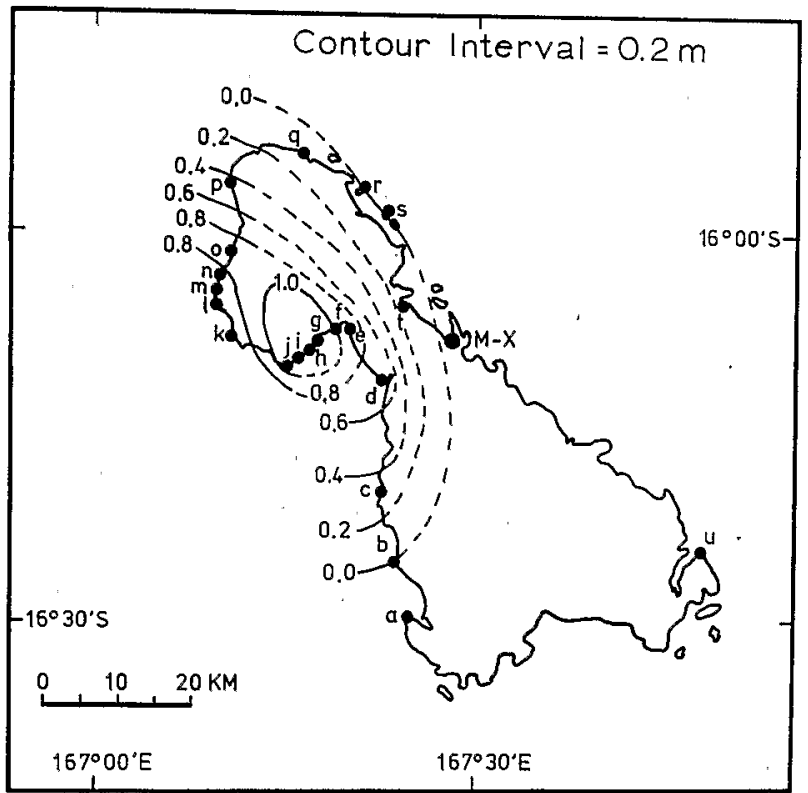

Fig. 8. Measurements (meters) of 1965 uplift made in September 1976, November 1977, and July 1979. The letters on the figure represent the places and amounts of uplift given in Table 2. The contours of uplift (contour interval $=0.2 \mathrm{~m}$ ) represent one of the simplest interpretations of the uplift pattern consistent with the measurements. progress may reveal further evidence of its tectonic significance.

From the quite different tilt directions demonstrated for south Malekula, north Malekula, and south Santo, it is clear that the three areas are each behaving semi-independently and that tilt discontinuities must separate each area from the others. The tilt discontinuity separating north from south Malekula has been clearly identified, but the tilt discontinuity between north Malekula and south Santo is beneath Bougainville Strait between the islands, and its exact location is not known.

The bathymetric map (Figure 2) shows that the ridge on the southern margin of the d'Entrecasteaux fracture zone approximately intersects the tilt discontinuity across central Malekula. North Malekula and south Santo are being underthrust by the d'Entrecasteaux fracture zone and are being uplifted relatively rapidly. In contrast, south Malekula is being underthrust by deeper ocean floor and is being uplifted relatively slowly. Deeper ocean floor is also being thrust beneath north Santo, although it has local uplift rates of up to several millimeters per year [Jouannic et al., 1980]. However, summit altitudes on west Santo indicate less total uplift in the north under which the deeper ocean floor is being underthrust.

\section{UPLIFT AsSOcIATED WITH THE AUGUST 1965 EARTHQUAKE SEQUENCE}

\section{Earthquake Sequence}

The main foreshock that initiated the 1965 earthquake sequence was under central south Santo at 0340 G.M.T. (1440 local time (LT)), August 11, 1965 (Figure 6). This shock was 
TABLE 2. Uplift Measured Along the Coast of Northern Malekula

\begin{tabular}{cllcccc}
\hline Station & Place Name & $\begin{array}{c}\text { Year } \\
\text { Measured }\end{array}$ & $\begin{array}{c}\text { Number of } \\
\text { Measurements }\end{array}$ & Range, $\mathbf{m}$ & Mean, m & $\begin{array}{c}\text { Standard } \\
\text { Devia- } \\
\text { tion, m }\end{array}$ \\
\hline a & Southwest Bay & 1977 & observation & & 0 & $*$ \\
b & Bamboo Bay & 1977 & observation & & 0 & $*$ \\
c & Dixon Reef & 1977 & 1 & 0.35 & $*$ \\
d & Lambubu Bay & 1976 & 15 & $0.67-0.87$ & 0.75 & 0.06 \\
e & West Bay & 1976 & 5 & $0.75-0.93$ & 0.89 & 0.08 \\
f & Horrok & 1976 & 1 & & 1.00 & $*$ \\
g & Brenwe & 1976 & 4 & $1.05-1.36$ & 1.20 & 0.14 \\
h & Liwout Point & 1976,1979 & 50 & $0.51-1.12$ & 0.79 & 0.18 \\
i & East Leviamp & 1976 & 4 & $1.00-1.25$ & 1.12 & 0.12 \\
j & West Leviamp & 1976 & 6 & $0.84-1.23$ & 1.07 & 0.14 \\
k & Elephant Point & 1976 & 17 & $0.55-0.81$ & 0.67 & 0.07 \\
1 & Win & 1979 & 24 & $0.41-0.79$ & 0.55 & 0.10 \\
m & Wihet Bay & 1979 & 23 & $0.45-0.71$ & 0.57 & 0.08 \\
n & Rambak & 1979 & 30 & $0.46-0.94$ & 0.66 & 0.12 \\
o & Npennanavet & 1976 & 10 & $0.73-1.00$ & 0.87 & 0.12 \\
p & Matanvat & 1976 & 4 & $0.38-0.45$ & 0.42 & 0.03 \\
q & Potovrou & 1977 & 1 & & 0.10 & $*$ \\
r & Atchin Island & 1977 & observation & & 0 & $*$ \\
s & Wala Island & 1977 & observation & & 0 & $*$ \\
t & Norsup & 1977 & 1 & & 0.15 & $*$ \\
u & Lamap & 1977 & observation & & 0 & $*$ \\
\hline
\end{tabular}

*Insufficient measurements for a standard deviation to be useful.

followed at 2231 G.M.T. (0931 LT) by the main shock ( $M s=$ 7 3/4) with its epicenter near western Malo. Both of these earthquakes had thrusting-type focal mechanisms [Johnson and Molnar, 1972]. The main aftershock, at 1240 G.M.T. (2340 LT), August 13, had its epicenter near the projected trench axis between Santo and Malekula. The main aftershock, which also had a thrusting focal mechanism [Ebel, 1980], was followed by a 2-m-high tsunami [Benoit and Dubois, 1971]. All three of these events were of $M s \geq 7.0$. The early aftershocks following the main shock define a rupture that extended from beneath south Santo to central Malekula, a distance of about $100 \mathrm{~km}$ (Figure 6). In contrast, the seismicity during the month following the main shock was more around than within the zone of early aftershocks. Therefore the early and the late aftershocks can each be taken to indicate a rupture that extended from south Santo to central Malekula. Since 1965, several moderately large thrust-type earthquakes have occurred down dip from the main August 1965 earthquakes.

\section{Measurement of the August 1965 Uplift}

Corals that were killed by emergence record the amount of August 1965 uplift at many points along the coast of Malekula. Prior to August 1965, as today, healthy coral reefs fringed most of the coasts of Malekula, Santo, and neighboring islands. Where uplift occurred, emerged 1965 corals form a distinct zone of very well-preserved dead corals at the inland edge of the living modern reef (Figure 7). The excellent preservation of the dead corals and the testimony of numerous witnesses guarantee that the well-preserved dead corals on Malekula emerged due to uplift in August, 1965.

The difference in level between the highest living corals and the highest dead 1965 corals provides a measure of the net change in level between August 1965 and the times of measurement in 1976, 1977, and 1979. At a given point on the shoreline the conditions that limited the maximum level to which corals could grow before August 1965 should not have changed significantly after the uplift. The uplift caused slight changes in shoreline geometry, but dominant wind directions, average wave height, and other factors can be assumed relatively constant. By measuring the difference in level between dead 1965 corals and living corals along the shoreline, the amount of uplift at many points was determined (Figure 8).

Many of the points on Figure 8 represent multiple measurements that were averaged to produce the given uplift values (Table 2). Where the coast is exposed to large waves, the maximum level at which corals can live varies by up to 0.10 or $0.20 \mathrm{~m}$, depending on local shoreline geometry. However, on sheltered coasts, such as at Dixon Reef (Figure 8, station c), the dead 1965 corals define a remarkably flat surface that is very consistent in height above the equally flat surface defined by the highest living corals. Thus in sheltered localities, multiple measurements of the 1965 uplift tended to vary by only a few centimeters from each other.

Measurements of 1965 uplift that were made in 1976, 1977, and 1979 define the general pattern of the uplift. Between stations $g$ and $a$, the zone of maximum uplift seems to be elongate in a NW-SE direction (Figure 8). NE and SW from this maximum, the amount of uplift decreases rapidly. Near the fault displacing the modern reef at Liwout Point (station h), $0.79 \mathrm{~m}$ of uplift was measured. This uplift is significantly less than at nearby stations, but the smallness of the uplift may be related to movement on nearby faults. At station $k$, the part of north Malekula closest to the projected trench axis, there was only $0.67 \mathrm{~m}$ of uplift measured in 1976 (Figure 8). Southward along the west coast, the 1965 uplift gradually decreases from $0.75 \mathrm{~m}$ at station $d$ to station $b$ where no evidence of 1965 uplift was detected. No evidence of 1965 uplift was found elsewhere on south Malekula, but subsidence is not precluded where evidence of uplift is lacking. Along the eastern coast of Malekula, the only uplift found was about $0.15 \mathrm{~m}$ at station $\mathrm{t}$ in a bay that deeply indents the coast.

Two previous reports of the uplift associated with the August 1965 earthquakes conflict with the measurements presented in Figure 8 and with each other. Mitchell [1968, 1971, p. 31] reported $2 \mathrm{~m}$ of uplift at Elephant Point (Table 2; station $\mathrm{k}$ on Figure 8) compared with our average measurement of $0.67 \mathrm{~m}$. Benoit and Dubois [1971] reported $0.50 \mathrm{~m}$ of uplift 
for this area, a value reasonably consistent with our measurement of $0.67 \mathrm{~m}$. Benoit and Dubois also reported $0.70 \mathrm{~m}$ of uplift on the northernmost point of Malekula, where we found scant evidence of possibly $0.1 \mathrm{~m}$ of uplift at station $\mathrm{q}$ (Figure 8; Table 2). On the northeast coast of north Malekula, Mitchell [1971, p. 26] found less than one third meter of 1965 uplift, but Benoit and Dubois [1971] reported $0.50 \mathrm{~m}$ of 1965 uplift for this area. At station $t$, in the area where Benoit and Dubois reported $0.50 \mathrm{~m}$ of 1965 uplift, we found $0.15 \mathrm{~m}$ of uplift recorded by a number of emerged corals. At station $t$ a coral head, Porites lobata, found growing in very shallow water, was partially emerged, and its upper surface was filled by uplift in 1965. Twelve annual growth bands in the part of the coral that continued living between the time of partial emergence in 1965 and sampling in 1977 indicate that, in this area, all of the uplift was in 1965 and subsidence did not follow [Taylor et al., 1979]. Had there been more uplift, the coral would have been totally emerged and killed at that time. Hence the report of $0.50 \mathrm{~m}$ of 1965 uplift for this area is probably in error.

We found no reliable evidence of 1965 uplift elsewhere on the northeast coast. Farther south along the east coast, Benoit and Dubois [1971] reported $0.60 \mathrm{~m}$ of uplift, but no supporting geologic evidence was found during our visit to the coast in that area. At locality M-X (Figure 8) a dead Porites lobata coral microatoll (the microatoll growth form indicates that the surface of the disk-shaped coral marked the upper limit of coral growth when it was alive) near high-tide level gave a radiocarbon age of $2970 \pm 200$ B.P. (sample M-X-2; Figure 8; Table 1). The net uplift rate for this locality is therefore only about $0.3 \mathrm{~mm} / \mathrm{yr}$, and little coseismic uplift is to be expected.

The conflict between some of the uplift values presented by Mitchell [1968, 1971], Benoit and Dubois [1971], and this paper could be due to (1) relatively crude methods of measurement used prior to this study or (2) vertical movements that occurred during the intervals between each set of reported measurements. A. H. G. Mitchell (personal communication, 1978) indicated that his methods for estimating uplift at Elephant Point were not as precise as those we used. Although he believes that there must have been at least $1.5 \mathrm{~m}$ ( 5 feet) of uplift at Elephant Point when he examined the site a few weeks after the earthquake sequence in 1965, Mitchell based his uplift estimates on (1) the height of the emerged 1965 reef above average low-tide level (not living corals), (2) the height of the raised beach-jungle boundary relative to higher high tide level, and (3) emergence of subtidal areas that previously had been about $1.2 \mathrm{~m}$ ( 4 feet) under water before the 1965 earthquakes. These methods give a rough estimate of emergence but do not compare with the precision obtained with our methods of measurement. At present, the discrepancy between our measurements and those of previous authors cannot be accounted for with certainty. There remains a possibility that vertical movements since 1965 have altered the original coseismic uplift pattern. The Porites lobata coral from station $t$ disputes post-1965 vertical movements along the eastern coast of Malekula as a cause for the contradictions between our uplift measurements and those of Mitchell [1971] and Benoit and Dubois [1971].

Detailed accounts of the effects of the 1965 earthquakes obtained from witnesses tended to be conflicting, probably because 11 to 14 years had elapsed between the earthquakes and our questions. However, P. Theuil stated that he measured 2.4 $\mathrm{m}$ of uplift at West Bay (station e; Figure 8; Table 2) 3 days after the major shocks of the 1965 earthquakes. We measured only $0.87 \mathrm{~m}$ of uplift due to the 1965 earthquakes in September 1976 at West Bay, but the witness asserted that the coast had subsided to its present level since 1965.

M. Louppe, who was at Unmet (station f; Figure 8; Table 2) in August 1965, described the earthquakes and associated uplift. About the time of the main shock at $0931 \mathrm{LT}$ on August 12,1965 , the sea receded from the land. Although M. Louppe and the villagers expected a tsunami to follow, the sea remained low. A. H. G. Mitchell (personal communication, 1977) confirmed that the sea receded permanently from beaches in western north Malekula. Stunned or stranded fish were collected by the village people. $M$. Louppe did not recall that the coast subsided noticeably in the years following the 1965 uplift. In 1976 we measured only $1.2 \mathrm{~m}$ of 1965 uplift at station g (Figure 8; Table 2) near Unmet. The following day, or perhaps 2 days later, M. Louppe had walked to Wilak, a village $3 \mathrm{~km}$ north-northwest of Elephant Point (station $\mathbf{k}$ ). That night at Wilak the sea receded but was followed shortly by a small tsunami. The timing of this tsunami is consistent with that reported to have occurred 41 hours after the main shock at 1240 G.M.T. or 2340 LT [Benoit and Dubois, 1971].

Elsewhere, at villages along the north and northeast coasts of Malekula, where we measured little or no 1965 uplift, people recalled that the sea had receded, but that it had returned slowly after periods estimated to range from 15 to 60 min. Since this event occurred in the daytime (people collected fish), it must have been associated with the main shock rather than the main aftershock that occurred at night and generated a tsunami. There seems to have been no noticeable tsunami following the seaward recession of water accompanying the main shock on August 12 (local time).

Several aspects of the 1965 uplift and the descriptions of witnesses suggest that the net uplift we measured in 1976, 1977 and 1979 may have resulted from a complex sequence of vertical movements. First, there is the description of recession of the sea near the time of the main shock all along the coast of north Malekula. Where we measured significant 1965 uplift, people tended to say that the sea receded permanently. Where we found no 1965 uplift, people said the sea receded and then came back after 15 to $60 \mathrm{~min}$ and that there was plenty of time to walk onto the reef and collect fish. This recession was not reported to have been followed by a tsunami and therefore may represent temporary uplift of perhaps several meters. Yet, we measured a maximum uplift of only $1.2 \mathrm{~m}$ (Figure 8) near Brenwe. Only $1.2 \mathrm{~m}$ of emergence of a fringing reef seems insufficient to strand fish, unless they were disoriented or stunned by the shocks or other phenomena associated with the earthquakes [e.g., Frohlich and Buskirk, 1980]. But low tide occurred at about 1130 LT on August 12, 1965, 2 hours after the main shock. Low tide would have contributed about $1.5 \mathrm{~m}$ to the regression of sea level from high-tide level on that date [U.S. Coast and Geodetic Survey, 1965]. Perhaps the combination of ebbing tide and uplift was sufficient to strand fish and greater uplift than we measured in 1976 was not required. Yet the statement that $2.4 \mathrm{~m}$ of uplift was measured at West Bay about 3 days after the earthquakes supports the suggestion that there may have been considerably more than $1.2 \mathrm{~m}$ of uplift at the time of the earthquake sequence but that the uplift decreased rapidly in the days or months following the earthquake sequence.

Observations made in 1979 at West Bay, Brenwe, and Npennanavet indicate that it is possible that there was more uplift in 1965 in these areas than is shown in Figure 8. At 
TABLE 3. Uplift Measured Along the South Coast of Santo in 1979

\begin{tabular}{|c|c|c|c|c|c|}
\hline Station & Place Name & $\begin{array}{c}\text { Number of } \\
\text { Measurements }\end{array}$ & Range, $\mathbf{m}$ & Mean, $m$ & $\begin{array}{c}\text { Standard } \\
\text { Devia- } \\
\text { tion, } \mathrm{m}\end{array}$ \\
\hline CLS & Cape Lisburn South & observation & & & \\
\hline CSW & Cape Sinotarip West & observation & & $\leq 0.10$ & \\
\hline CSE & Cape Sinotarip East & 3 & $0.24-0.30$ & 0.27 & 0.03 \\
\hline TAS & Tasmaloum & 4 & $0.33-0.69$ & 0.47 & 0.16 \\
\hline TAN & Tangoa & 7 & $0.23-0.38$ & 0.29 & 0.06 \\
\hline $\mathrm{ABO}$ & Abounatari & 12 & $0.15-0.33$ & 0.23 & 0.06 \\
\hline PAL & Palekula & observation & & $\leq 0.05$ & \\
\hline
\end{tabular}

these sites, no coral heads sufficiently large to have been alive in 1965 were found at depths shallower than about 0.5 to 1.0 $\mathrm{m}$ (estimated) deeper than the shallowest living corals. These observations serve to limit the maximum amount of 1965 uplift to no more than about $1 \mathrm{~m}$ more than we measured at West Bay, Brenwe, and Npennanavet. This applies only to uplift that may have lasted for a sufficient period to have killed these coral heads. But, in no way do these observations prove that more uplift than we show in Figure 8 occurred in 1965 or subsequently. It is possible that in 1965 at these sites there were no coral heads living at depths of as much as about $1.0 \mathrm{~m}$ deeper than the shallowest presently living corals. More observations and measurements would be required to fully exploit the information recorded by the corals.

Evidence of recent uplift was also found on the coast of south Santo and islands off the coast of south Santo. However, it is extremely uncertain whether this uplift was associated with the 1965 earthquake sequence. Unlike Malekula, uplift of south Santo in 1965 was not documented by geologists and witnesses who were on the scene. Some Santo residents claimed that south Santo had been uplifted about $0.3 \mathrm{~m}$ in association with an earthquake within recent decades, but they could not specify the year of the event. South Santo is within the zone of rupture inferred for the 1965 earthquakes, but uplift associated with other earthquakes since 1965 or with aseismic movements cannot be confidently discounted (Figure 6).

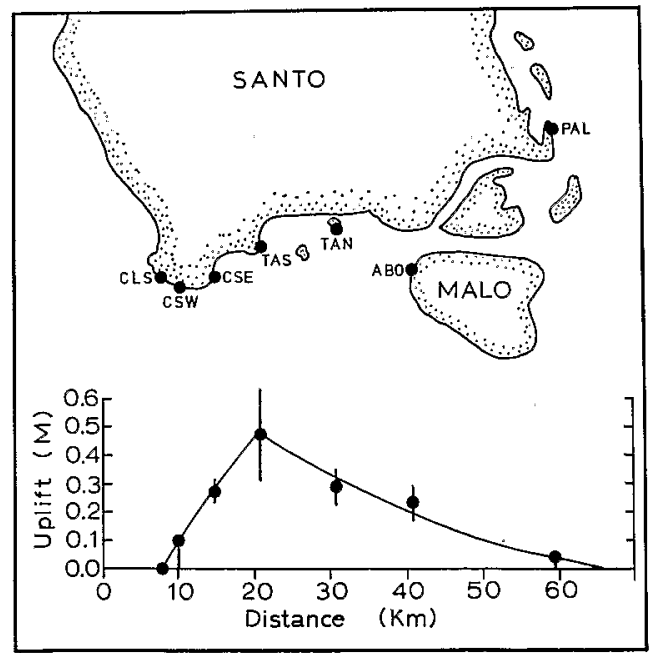

Fig. 9. Measurements of uplift on the south coast of Santo. The age of this uplift is not known exactly, but it is estimated to have occurred in the past 20 years. At the bottom is an E-W profile on which the uplift measurements are plotted. Station TAS, where the greatest recent uplift was measured, is approximately where the NNW-SSE axis of the mountains of west Santo intersect the south coast.
Measurements of uplift based on corals killed by emergence give general definition to the pattern of recent uplift for south Santo (Table 3; Figure 9). The uplift measurements presently available are inadequate to define the geographic limits of the uplifted area, but they are located in such a way that a preliminary uplift profile can be inferred. This uplift pattern differs from that of Malekula because both the eastern and western hingelines of the uplift profile are defined. The uplift profile is consistent with that which would be caused by an eastward dipping burried thrust fault beneath Santo. Because the time and geographic extent of uplift of south Santo are unknown at present, no attempt has yet been made to model the associated faulting.

\section{DISCUSSION}

Seismotectonic Significance of Subduction of D'Entrecasteaux Fracture Zone

The two most significant aspects of the long-term tectonic pattern are the existence of three adjacent areas having distinctly different tilt directions and the alignment of the flanks of the d'Entrecasteaux fracture zone with the tilt discontinuity across Malekula and the tectonic feature across south Santo. North and south Malekula and Santo have been uplifted with tilt directions generally away from the subduction zone. Tilting of the seaward zone of uplift away from the subduction zone has been observed in other arc systems [Fitch and Scholz, 1971; Plafker, 1972; Kaizuka et al., 1973]. However, a smooth ocean floor is not being subducted beneath Santo and Malekula. Rather, we assume that the rugged topography of the d'Entrecasteaux fracture zone that is observed on the IndianAustralian plate is representative of that which is presently on the underthrust plate beneath Santo and Malekula (Figure 2). A faultlike feature in the underthrusting plate east of Santo implies that the d'Entrecasteaux fracture zone extends far downdip from the subduction zone [Isacks and Barazangi, 1977; Pascal et al., 1978; Chung and Kanamori, 1978b]. High topography on the south flank of the d'Entrecasteaux fracture zone [Andrews et al., 1975] is being subducted beneath Malekula, and a similar ridge on the north flank is being subducted beneath Santo. The fracture zone trends E-W, but convergence is toward $N 75^{\circ} \mathrm{E}$. The intersection between the fracture zone and the New Hebrides arc is thus slowly migrating northward at a rate of 2 or $3 \mathrm{~cm} / \mathrm{yr}$. This implies a more complex interaction between the fracture zone and arc than when a ridge is oriented in the direction of convergence, and it constantly intersects one area of an arc.

Subduction of the ridge on the southern margin of the d'Entrecasteaux fracture zone may account for the contrasting tilt directions of north and south Malekula (Figure 10). First, since higher topography has been subducted beneath north 


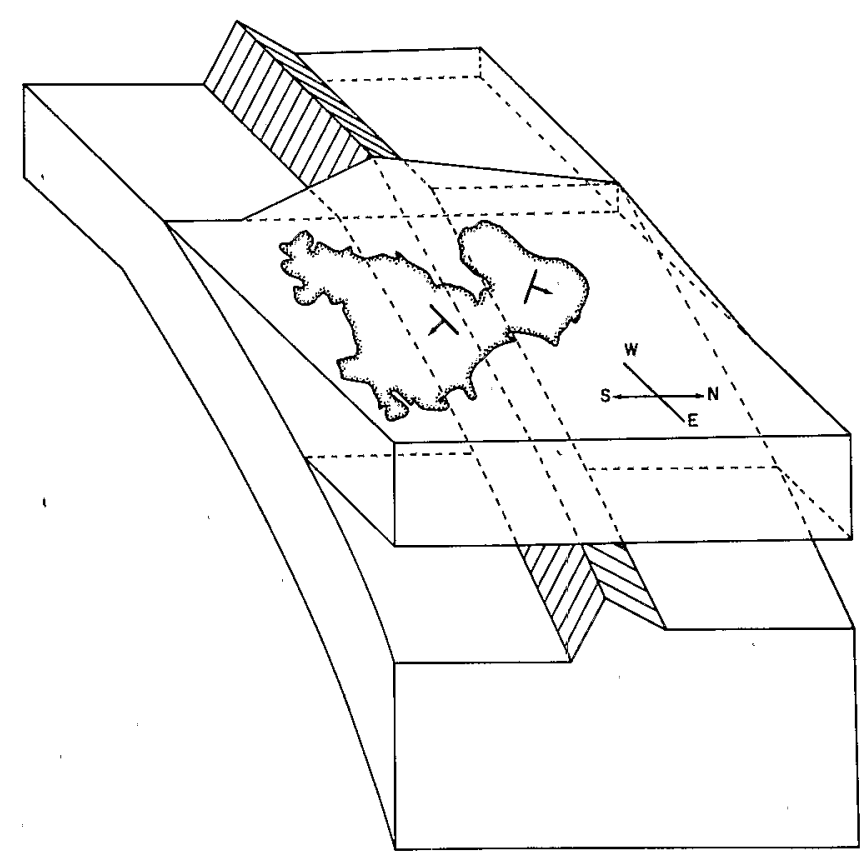

Fig. 10. Model for uplift and tilting of Malekula. The d'Entrecasteaux fracture zone trends $\mathrm{E}-\mathrm{W}$ but is moving $\mathrm{N} 75^{\circ} \mathrm{E} \pm 11^{\circ}$ with respect to the Pacific plate and the New Hebrides Islands [Pascal et al., 1978]. North Malekula is being underthrust by the higher ocean floor of the central part of the d'Entrecasteaux fracture zone, while south Malekula is being underthrust by deeper ocean floor. This difference may partly account for the more rapid uplift of north Malekula. Tilting away from the ridge on the fracture zone may explain why neither north Malekula nor south Malekula has been tilting in a direction perpendicular to the arc trend of $\mathrm{N} 20^{\circ} \mathrm{W}$.

than south Malekula, north Malekula has been uplifted more than south Malekula for the past few hundred thousand years. Second, subduction of the northward migrating ridge may give north Malekula a northward component of tilt. Combined with the general tendency of the upper plate to tilt eastward in the direction of dip of the main thrust zone, the northward component may produce a net NE tilt direction. Third, passive response of the upper plate to subduction of a major topographic feature combined with uplift and tilting of adjacent north Malekula may control tilting of the northern part of south Malekula. The southeastward tilt direction shows that near the tilt discontinuity, south Malekula is simply tilting away from the more rapidly uplifting north Malekula to which it is partially coupled across the tilt discontinuity.

There is no obvious characteristic of the d'Entrecasteaux fracture zone west of the New Hebrides arc that accounts for the inferred tilt discontinuity between Santo and Malekula. Unfortunately, we can only deduce the character of the underthrust plate beneath Santo and Malekula from the part that has not yet been subducted. Possibly, the discontinuity between Santo and Malekula is the result of subduction of a seamount or segment of high topography that has disappeared from view through the subduction process.

The influence of the d'Entrecasteaux fracture zone on the blocklike behavior and tectonic discontinuities of the upper plate suggests that rough topography on subducted ocean floor may be directly reflected in deformation of the upper plate and thereby may strongly influence the locations of block boundaries and the tilt direction of each block. Once established, these block boundaries may tend to persist as lines of weakness along which blocks most easily move relative to one another, even if the subducting topography changes through time. If the underthrusting topography controls block boundaries and tectonic patterns, then the topography may also influence the limits of areas ruptured by major earthquakes along the arc. If topography influences the structural blocks and seismicity, then a simple elastic model for uplift above a thrust fault must be applied with caution to the New Hebrides arc and similar tectonic settings. Perhaps the simplest and most realistic way to view the uplift and tilting of Malekula and Santo is as the jostling of blocks in the upper plate as it is underthrust by rugged topography.

The intersections of the northern and southern flanks of the d'Entrecasteaux fracture zone with Santo and Malekula mark approximately the ends of the 1965 rupture zone. Moreover, the northern end of the 1965 rupture zone in Santo is approximately the southern end of a rupture zone associated with a major sequence of thrust-type earthquakes in 1973-1974 [Pascal et al., 1978]. The tectonic discontinuity across Santo has thus twice been observed to have been near the end of a seismic rupture. Ebel [1980] defined three barriers to propagation of seismic rupture in the Santo-Malekula area through analysis of the 1965 earthquake sequence. One of the barriers corresponds to the discontinuity across Malekula and another to the discontinuity across Santo. The third barrier corresponds to the tilt discontinuity inferred between Santo and Malekula.

The block geometries may influence the area of the main thrust zone that ruptures in a given sequence of thrust-type earthquakes. Or, more likely, the boundaries between blocks are a manifestation of deeper-seated interactions between the two plates which control both rupture lengths and block boundaries. If seismic ruptures repeatedly begin and end in a particular area, the overlying upper plate may tend to be weakened and a block boundary may develop. The block boundaries may also mark the limit of uplift associated with a seismic rupture. This is indicated by the rapid decrease in 1965 uplift across the Malekula tilt discontinuity. The effect of the other two discontinuities cannot be properly evaluated until we know whether Santo was uplifted in 1965. It is possible that other block boundaries of seismotectonic significance will be identified in the Santo-Malekula region.

Although the tilt discontinuity between Santo and Malekula did not mark the end of a seismic rupture in 1965, it may have in the past and may in the future. The age of the recent uplift of south Santo would indicate the significance of this tilt discontinuity. If it acted as the northern limit of the 1965 coseismic uplift, then the quota of uplift for south Santo was not affected by the 1965 earthquakes despite the extent of the rupture. In this case, one might suspect a relationship between uplift of south Santo and other earthquakes.

\section{Uplift Pattern}

The uplift associated with the 1965 earthquake sequence provides an example of one of the increments of uplift that contributes to the net long-term tectonic pattern. The degree of similarity of the 1965 uplift pattern to the long-term net uplift pattern can provide clues to the relationship between longterm uplift patterns and the individual phases of uplift that sum to the net pattern. This is the principal reason for comparing the 1965 and long-term uplift patterns. A potential problem is that measurements of uplift were made in 1976, 1977, and 1979,11 to 14 years after the coseismic uplift, and the measurements may thus include postseismic adjustments as well. 

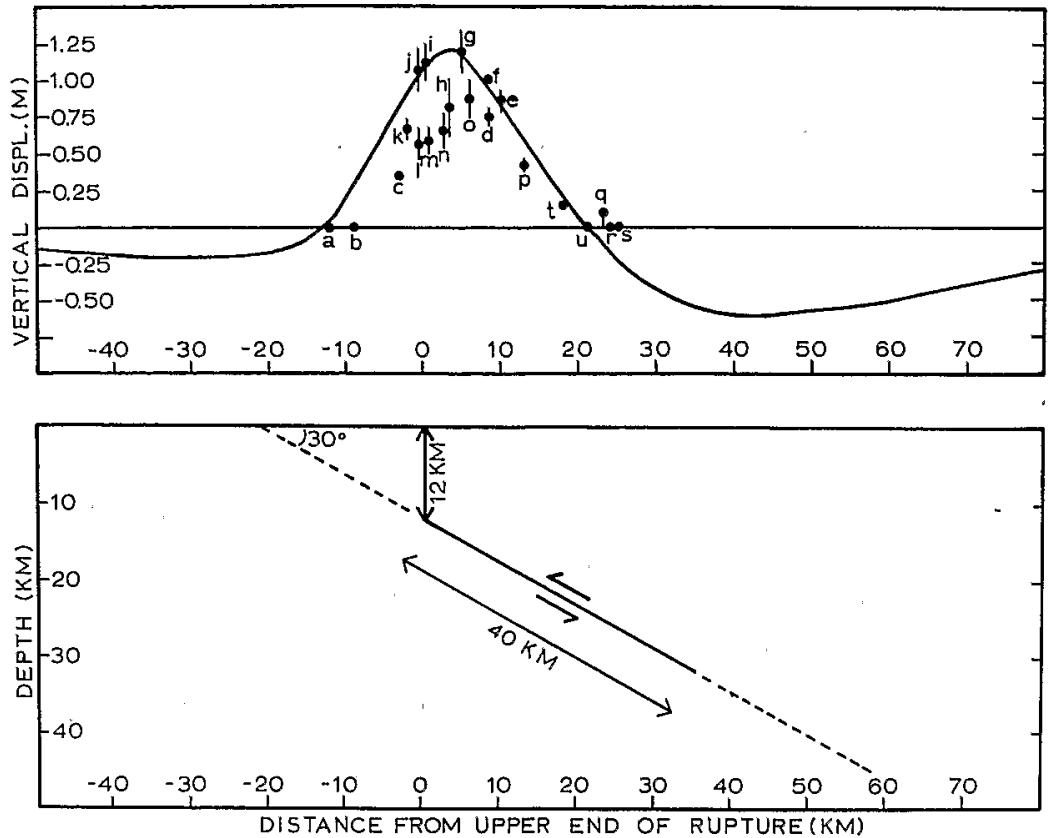

Fig. 11. NE profile with 1965 uplift data and calculated displacement by the method of Savage and Hastie [1966]. The uplift measurements, located on Figure 8 and listed in Table 2, are marked by circles. Those lacking error bars represent too few measurements for a standard deviation to be useful, but are believed to be fairly accurate. The fault that generated the calculated deformation dips $30^{\circ}$ from a depth of $12 \mathrm{~km}$ to a depth of $32 \mathrm{~km}$ such that the down dip width of the rupture is $40 \mathrm{~km}$. The strike length of the fault is $105 \mathrm{~km}$. Fault slip had to be about $5.3 \mathrm{~m}$ to produce as much uplift as measured on north Malekula. This fault model does not provide a unique fit to the uplift measurements. Numerous other fault models can generate an uplift profile that will match the uplift measurements as well.

The area of 1965 uplift corresponds fairly well with the area overlying the 1965 zone of rupture. There are two possible exceptions to this generality. The main foreshock and main shock clearly imply that the rupture began beneath southern Santo. Yet uplift of south Santo has not been shown to have occurred in 1965. The 1965 uplift extends into south Malekula, although the early aftershocks indicate that the rupture ended approximately beneath central Malekula.

\section{Model of the Fault and Deformation Associated With 1965 Earthquakes}

A profile of surface deformation for the 1965 uplift of north Malekula (Figure 11) has been calculated by the method of Savage and Hastie [1966]. The fault parameters (width $=40$ $\mathrm{km} ; \operatorname{dip}=30^{\circ} ;$ length $=105 \mathrm{~km} ;$ slip $=5.3 \mathrm{~m}$; depth $=12 \mathrm{~km}$ ) are reasonable in view of the characteristics of the 1965 earthquake sequence and the regional seismicity [Pascal et al., 1978]. The fault length of $105 \mathrm{~km}$ was chosen on the basis of the locations of the main shocks and early aftershocks of the 1965 earthquake sequence. The $30^{\circ}$ dip of the thrust fault was taken from the profile of the New Hebrides Benioff zone at a depth of about $12 \mathrm{~km}$ [Pascal et al., 1978]. Other parameters, the fault width, slip, and depth at the shallow end of the fault plane, were varied within reasonable limits to produce an uplift profile similar to the 1965 uplift pattern across north Malekula. One test of the validity of the fault model is to calculate the stress drop required by a fault with the model parameters. The calculation is as follows:

$$
\Delta \tau=\eta \mu \frac{s}{w}=33 \text { bars }
$$

where $\Delta \tau$ is the stress drop, $\eta=0.84$ for a rectangular fault with a ratio of width to length equal to 0.38 [Chinnery, 1969], $\mu$
$=$ rigidity coefficient $=3 \times 10^{11} \mathrm{cgs} ; s$ is slip equal to $5.3 \mathrm{~m} ; w$ is the width of the fault equal to $40 \mathrm{~km}$ (Figure 11). The stress drop of 33 bars is consistent with estimates of stress drops in thrust zones [Kamamori and Anderson, 1975].

The 1965 uplift data are projected onto a NE-SW profile for comparison with the fault model because NE is the direction of long-term tilt for north Malekula (Figure 11). N70 $\mathrm{E}$, the direction perpendicular to the arc trend, is an alternative profile orientation. Even when points which may have been influenced by proximity to the lateral edge of the uplifted area are ignored, some other points fall below one another and below the calculated uplift curve.

The fault deformation model shows that the 1965 uplift of north Malekula could have been caused by displacement on the main thrust zone. However, one problem is that the 1965 uplift data do not define the uplift pattern in sufficient detail. For example, on its southwest end, the shape of the uplift profile (Figure 11) is not known southwest of Elephant Point (station $\mathrm{k}$ ). Since the southwest limit of the uplifted area is not known, one is free to assign a range of widths to the uplifted region. Another problem is the lack of information on the zone of subsidence that is assumed to exist NE of the zone of uplift. The shape and amplitude of the area of subsidence that may have accompanied uplift are required to adequately define the vertical deformation pattern. Without measurements to define the complete 1965 deformation pattern, numerous combinations of fault parameters of significantly different dimensions can produce an uplift profile similar to that shown by the 1965 uplift measurements in Figures 8 and 11 .

Two additional factors bear on the applicability of the fault displacement calculations. First, if there was significant movement in 1965 on the surface faults cutting northwestern Malekula, then the calculations that assume a single buried thrust 
fault are not entirely valid. The long-term fault block style of deformation in southwestern north Malekula argues against simple elastic behavior of the upper plate. Second, there is the influence of subduction of the topography on the d'Entrecasteaux fracture zone. If a ridge along the southern margin of the fracture zone is responsible for the rapid uplift rates of north Malekula and for the tilt discontinuity across central Malekula, then, again, a simple fault displacement model in a homogeneous half space is probably not valid. The lack of symmetry of the long-term deformation pattern with respect to the $\mathrm{N} 20^{\circ} \mathrm{E}$ arc trend also suggests that a simple fault model is not applicable. In conclusion, it is unlikely that a simple thrust fault model adequately describes the mechanism of uplift for north Malekula.

\section{Comparison of the 1965 and Long-Term Uplift Patterns}

The 1965 uplift data, when projected on a NE-SW profile (Figure 11), compare well with the long-term uplift pattern indicated by terraces and by topographic profiles across north Malekula (Figure 5). The terraces, the topographic profiles, and the 1965 uplift pattern all indicate maximum uplift along a line trending NW-SE through north Malekula. The zone of maximum long-term uplift rate (Figures 4 and 5) coincides remarkably well with the area of maximum 1965 uplift (Figure 8). Southwestward from the maximum, the amount of both long-term and 1965 uplift decreases rapidly across the area of closely spaced NW-SE trending faults.

Along the northeast coast, where terraces indicate the minimum long-term uplift for north Malekula, no evidence of 1965 uplift was discovered except at station t. Annual growth bands in a coral indicate that uplift at this site did not exceed about $0.15 \mathrm{~m}$ in 1965 and that if subsequent vertical movements occurred, they were less than a few centimeters. Also, evidence of 1965 uplift was absent on the healthy fringing reefs along the east coast of south Malekula, where terraces indicate less long-term uplift than anywhere on north Malekula. Subsidence during or subsequent to the 1965 earthquake sequence is possible for sites where there is an absence of evidence for uplift.

When considered in detail, there are some clear differences between the 1965 and the long-term uplift patterns. The longterm uplift rate decreases by $35 \%$ across the tilt discontinuity between station e and station d. Yet, in 1976 we measured $0.87 \mathrm{~m}$ of 1965 uplift at West Bay (station e) and $0.75 \mathrm{~m}$ at Lambubu Bay (station d) (Figure 8), a decrease of only 15 per cent. The long-term uplift pattern also indicates a more rapid decrease of uplift southward from Lambubu Bay than is observed in the 1965 uplift data. From Lambubu Bay southward the emerged Holocene reef terrace is progressively lower. At Lambubu Bay the Holocene terrace is several meters above high-tide level, but at Tisvel Bay it is only barely emerged (Figure 4). Although there is no emerged Holocene terrace for some kilometers south of Tisvel Bay, there is a double solution notch in the sea cliffs. The lower notch corresponds to high-tide level prior to the 1965 uplift of about $0.35 \mathrm{~m}$ that was measured from emerged corals in this area. If the upper notch is also Holocene, then there has been about 1 to $1.5 \mathrm{~m}$ of Holocene emergence of the coast between Tisvel Bay (Figure 4) and Dixon Reef, $9 \mathrm{~km}$ farther south. Although the lack of an emerged Holocene reef near Dixon Reef indicates minimal net uplift of the area in the past $10^{3}$ to $10^{4}$ years, we found $0.35 \mathrm{~m}$ of 1965 uplift in 1977.
The emerged terraces along the northeastern coast of north Malekula indicate long-term average uplift rates of about 0.5 $\mathrm{mm} / \mathrm{yr}$ [Jouannic et al., 1980]. Yet there was no detectable 1965 uplift on most of the northeast coast.

The differences between the 1965 and the long-term uplift patterns could be attributed to one or more of several possible causes. First, the 1965 uplift pattern may be atypical. The long-term uplift pattern recorded by the terraces is certainly the net average pattern of uplift, but the net uplift pattern may be the average deformation imposed by the summation of widely variable individual coseismic vertical movements. For example, the 1965 rupture may have extended farther south than past ruptures and thereby accounts for more 1965 uplift of the west coast of south Malekula than is consistent with the long-term record. Second, interseismic or future coseismic vertical movements may modify the 1965 uplift pattern so that the net permanent 1965 uplift pattern more closely resembles the long-term uplift pattern. Brown et al. [1977] reported an aseismic contribution to vertical deformation in the area of the 1964 Alaskan earthquake during the decade following the earthquake. Perhaps the initial uplift imposed by slip on the main thrust fault resulted in elastic deformation. The uplifted tilt block geometry may cause readjustments in the elastic deformation pattern to bring it into accord with the long-term block-controlled uplift pattern.

The pattern of 1965 uplift is sufficiently similar to the longterm uplift pattern of north Malekula to assert the great significance of coseismic uplift to the tectonic evolution of the central New Hebrides arc. Since the 1965 and long-term uplift patterns are so similar, it is likely that there have been many coseismic uplifts similar to that of 1965.

Although the age of the most recent uplift of Santo is unknown, it is useful to consider our measurements of recent uplift of southern Santo with the long-term uplift pattern. The few available measurements show (Figure 9; Table 3) that the maximum recent uplift of about $0.47 \mathrm{~m}$ occurs toward the western side of south Santo. This is where the axis of the mountain belt of western Santo intersects the south coast and where Holocene reef terraces indicate the fastest uplift [Jouannic et al., 1980]. This implies that the highest mountains on Santo are in the west because their topographic axis has been the axis of maximum uplift for a long time.

\section{Possible Seismic Recurrence Intervals for North Malekula}

We have, as yet, no firm estimate of the recurrence interval for earthquakes that are accompanied by the uplift of north Malekula. However, a maximum recurrence interval can be estimated if some assumptions are accepted: (1) all of the 1965 uplift that we measured is permanent uplift and future vertical movements will not subtract from it, (2) all uplift of north Malekula is coseismic, and (3) the amount of uplift accompanying the 1965 earthquake sequence is typical of past thrusting-type earthquakes associated with rupturing beneath north Malekula. The long-term uplift rate can be calculated where the altitudes and ages of Holocene and older terraces are known. For example, near station g (Figure 8) on Malekula, coral from a terrace that reaches $19.5 \mathrm{~m}$ higher than the living reef is $5600 \pm 500$ years old (sample M-Y-2; Table 1). Sea level 5600 years ago was close to its present level, so that in 5600 years the terrace has been uplifted $19.5 \mathrm{~m}$ for an average uplift rate of about $3.5 \mathrm{~mm} / \mathrm{yr}$. At station $\mathrm{g}, 1.20 \mathrm{~m}$ of 
1965 uplift was measured in 1976. Thus an earthquake producing $1.20 \mathrm{~m}$ of uplift must occur every 340 years to maintain an uplift rate of $3.5 \mathrm{~mm} / \mathrm{yr}$. The more of the $1.20 \mathrm{~m}$ of uplift that is lost to subsidence, the shorter the recurrence interval must be to produce the observed long-term uplift rate. If, as in Shikoku, Japan, only 10 to $20 \%$ of the coseismic deformation is permanent, then the recurrence interval is on the order of 35 to 70 years.

Perspective on recurrence intervals is offered by considering the convergence rate of $11 \mathrm{~cm} / \mathrm{yr}$ at the New Hebrides arc. Assuming that all convergence is accommodated by seismic slip, the recurrence interval for significant seismic slip is 340 years, and the fault dimensions of our model are valid, then each earthquake would require $37 \mathrm{~m}$ of slip and a stress drop of 236 bars. In contrast, a recurrence interval of 35 years suggests $3.85 \mathrm{~m}$ of slip and a stress drop of 24 bars per earthquake, a more plausible value. Of course, aseismic slip or seismic slip not contributing to net uplift are some possible alternative factors.

\section{SUMMARY AND CONCLUSIONS}

The long-term uplift history of Santo and Malekula suggests that the New Hebrides arc in this area is subdivided into at least four areas that have significantly different tectonic histories. The boundaries between the subdivisions consist of tilt discontinuities across Malekula and between Santo and Malekula, and a third tectonic discontinuity E-W across south Santo. For the latter feature we have no firm evidence that it also marks a change in tilt direction. Notably, none of the three areas for which tilt directions were determined has been tilted perpendicular to the $\mathrm{N} 20^{\circ} \mathrm{W}$ arc trend.

In general, the long-term pattern of uplift for south Santo and north Malekula is that of tilting away from the trench, with increasing uplift rates from their east coasts toward their west coasts. However, just inland from their west coasts are the axes of maximum long-term uplift to the west of which uplift rates decrease rapidly and net tilting actually may be toward the west. This uplift pattern is available for study only because of the unusual location of Santo and Malekula very close to the underlying main thrust zone where the inner trench slope is normally located.

The influence of the subducted seafloor topography of the d'Entrecasteaux fracture zone on the overlying upper plate deformation is the most significant aspect of deformation in the Santo-Malekula region. Evidence for the influence of the d'Entrecasteaux fracture zone on the deformation pattern includes (1) the approximate alignment of the north and south flanks of the d'Entrecasteaux fracture zone with the tectonic discontinuities across Santo and Malekula, (2) the greater uplift rates for north Malekula and the greater altitude of south - Santo under which topographically higher sea floor is being subducted, and (3) the tilt directions on both sides of the Malekula tilt discontinuity compared with topography being subducted. Yet the tilt discontinuity between Santo and Malekula apparently is not related to topography on the part of the downgoing plate that has not yet been subducted. Quite possibly, this discontinuity is related to some topographic element that disappeared beneath the upper plate in the past.

In addition to the long-term uplift pattern, the d'Entrecasteaux fracture zone seems to influence the geometry of seismic rupture zones and the area of associated coseismic uplift. The 1965 and 1973-1974 rupture zone boundaries that are nearly coincident with the tectonic discontinuities across Santo and Malekula indicate the strength of the relationship between subducting topography and seismotectonics on a very short time scale as well as on the time scale represented by reef terraces. Clearly, the d'Entrecasteaux fracture zone is the unifying factor in the tectonic history and shallow seismicity in the central New Hebrides arc.

The 1965 uplift pattern generally reflects the long-term uplift pattern, but there seems to be a few differences. First, the absence of detectable 1965 uplift along most of the NE coast of north Malekula is not consistent with the local long-term uplift rate of $0.5 \mathrm{~mm} / \mathrm{yr}$. Future seismic or aseismic movements may compensate for lack of uplift in this area. Along the west coast from north to south across the tilt discontinuity, the long-term uplift rate decreases more rapidly than does the 1965 uplift. The very small amount of long-term uplift near Dixon Reef, despite $0.35 \mathrm{~m}$ of 1965 uplift, is a clue that the 1965 uplift of that area may not be permanent.

The 1965 uplift pattern can be modeled by thrust faults having parameters consistent with the geologic setting and the 1965 earthquake sequence. However, the uplift data do not constrain the model sufficiently to guarantee that its parameters faithfully represent the fault. Many different fault models can generate an uplift profile that fits our 1965 uplift measurements. A number of factors may have acted to interfere with a simple elastic response to faulting. These include (1) surface faulting in western north Malekula, (2) domination of the deformation pattern by the long-established tilt blocks and the tilt discontinuities between them, and (3) strong influence on the uplift pattern by topography on the d'Entrecasteaux fracture zone. Because at least some if not all of these factors affect the uplift pattern, an elastic model is likely to be misleading. A better way to think of the upper plate may be as a series of loosely coupled blocks whose movements are dominated by rugged topography on the surface of the underthrusting plate. However, the consistency of the uplift pattern of north Malekula with our elastic models suggests that much of the deformation is accounted for by a thrust fault similar to that in our model.

The similarity between the 1965 uplift and the long-term block-controlled uplift patterns indicates that (1) the 1965 uplift is a typical seismic uplift pattern that contributes an increment to the long-term uplift pattern, (2) the factors that determined the long-term uplift pattern are still affecting individual uplifts, and (3) since the long-term uplift pattern is influenced by the d'Entrecasteaux fracture zone, it must also control coseismic uplift patterns, and a simple elastic model is therefore probably misleading. Likewise, the general correspondence between the 1965 zone of seismic rupture, the area of 1965 uplift, the tilt block boundaries, and the ridges on the fracture zone flanks implies a connection between block boundaries and extent of seismic rupture. Given this relationship, then the topography of the d'Entrecasteaux fracture zone influences both the pattern of block-controlled uplift and segmentation of the arc in terms of seismicity. If this is true, then the first step in predicting the location and extent of future shallow thrusting earthquakes in the area is to identify other tilt blocks in the region and determine when each block was last uplifted. The most valuable information would be the seismic recurrence interval for each block. At present, the recurrence interval for north Malekula is uncertain by a factor of approximately ten. 
This study is a first step in evaluating the recurrence interval for thrusting earthquakes accompanied by uplift of north Malekula. A few assumptions allow estimation of the maximum recurrence interval: (1) all 1965 uplift that we measured is permanent, (2) all uplift of north Malekula is coseismic, and (3) the 1965 uplift is typical of past and future coseismic uplifts affecting north Malekula. Given these assumptions, the maximum seismic recurrence interval is about 340 years. However, if as little as 10 to $20 \%$ of the 1965 uplift that we measured is ultimately permanent, then the recurrence interval is only 35 to 70 years.

Acknowledgments. The authors wish to express their appreciation for help and advice from the staffs of the Service des Mines and the Geological Survey, Port Vila, New Hebrides. We especially wish to thank the people of Malekula, Santo, Malo, Tangoa, Araki, Atchin, and Wala for their cooperation and hospitality during our visits to their islands. Radiometric dates were prepared by W. S Broecker and John Goddard of Lamont-Doherty Geological Observatory, Palisades, New York, and by J.-C. Fontes, of the Laborotoire d'Hydrologie et de Geochimie Isotopique, Universite de Paris-Sud, Orsay, France. John Wells of Cornell University kindly identified the coral samples in Table 1 for radiometric dating. The authors benefitted from the suggestions of R. Cardwell, M. Bevis, D. E. Karig, S. Schilt, J. Clark, and J. Adams. This research was supported by funds from NSF Grants EAR-77-13685 and EAR-78-15188 and by the Office de la Recherche Scientifique et Technique Outre-Mer (O.R.S.T.O.M.), Noumea, New Caledonia. Cornell Contribution 647.

\section{REFERENCES}

Andrews, J. E., et al., Site 286, in Initial Reports of the Deep-Sea Drilling Projeci, vol. 30, pp. 69-173, U.S. Government Printing Office, Washington, D. C., 1975.

Benoit, M., and J. Dubois, The earthquake swarm in the New Hebrides archipelago, August, 1965, Recent Crustal Movements, Roy. Soc. N. Z. Bull., 9, 141-148, 1971.

Bloom, A. L., W. S. Broecker, J. M. A. Chappell, R. K. Matthews, and K. J. Mesolella, Quaternary sea level fluctuations on a tectonic coast: New 230-Th/234-U dates from the Huon Peninsula, New Guinea, Quaternary Res., 4, 185-205, 1974.

Brown, L. D., R. E. Reilinger, S. R. Holdahl, and E. I. Balazs, Postseismic crustal uplift near Anchorage, Alaska, J. Geophys. Res., 82, 3369-3378, 1977.

Chappell, J. M. A., Geology of coral terraces, Huon Peninsula, New Guinea: A study of Quaternary tectonic movements and sea level changes, Geol. Soc. Amer. Bull., 85, 553-570, 1974.

Chase, C. G., Tectonic history of the Fiji Plateau, Geol. Soc. Amer. Bull., 82, 3087-3110, 1971.

Chinnery, M. A., Theoretical fault models, A Symposium on Processes in the Focal Region, Publ. Dominion Observ., Ottawa, 37(7), 211-223, 1969.

Chung, W.-Y., and H. Kanamori, A mechanical model for plate deformation associated with aseismic ridge subduction in the New Hebrides arc, Tectonophysics, 50, 29-40, 1978 a.

Chung, W.-Y., and H. Kanamori, Subduction process of a fracture zone and aseismic ridges-The focal mechanism and source characteristics of the New Hebrides earthquake of January 19, 1969 and some related events, Geophys. J. Roy. Astron. Soc., 54, 221-240, $1978 b$.

Dubois, J., J. Dupont, A. Lapouille, and J. Recy, Lithospheric bulge and thickening of the lithosphere with age: Examples in the southwest Pacific, in International Symposium on Geodynamics in the Southwest Pacific, pp. 371-380, Technip, Paris, 1977.

Ebel, J. E., Source processes of the 1965 New Hebrides Islands earthquakes inferred from teleseismic wave forms, Geophys. J., in press, 1980.

Falvey, D. A., Analysis of paleomagnetic data from New Hebrides, Bull. Aust. Explor. Geophys., 9, 117-123, 1978.

Fitch, T. J., and C. H. Scholz, Mechanism of underthrusting in southwest Japan: A model of convergent plate interactions, J. Geophys. Res., 76, 7260-7292, 1971.
Frohlich, C., and R. E. Buskirk, Can fish detect seismic waves?, Abnormal Animal Behavior Prior to Earthquakes?, Open File Rep. 80453, U.S. Geol. Surv., Reston, Va., 1980.

Isacks, B. L., and M. Barazangi, Geometry of Benioff zones: Lateral segmentation and downwards bending of the subducted lithosphere, in Island Arcs, Deep Sea Trenches and Back-Arc Basins, Maurice Ewing Ser., vol. 1, edited by M. Talwani and W. C. Pitmann, III, pp. 99-114, AGU, Washington, D. C., 1977.

Johnson, T., and P. Molnar, Focal mechanisms and plate tectonics in the southeast Pacific, J. Geophys. Res., 77, 5000-5032, 1972.

Jouannic, C., F. W. Taylor, A. L. Bloom, and M. Bernat, Late Quaternary uplift history from emerged reef terraces on Santo and Malekula Islands, central New Hebrides island arc, Tech. Bull. 3, Econ. and Soc. Comm. for Asia and the Pac. and the Comm. for Coord. of Joint Prospect. for Miner. Resourc. in S. Pac. Offshore Areas (CCOP/SOPAC), Suva, Fiji, in press, 1980.

Kaizuka, S., T. Matsuda, M. Nogami, and N. Yonekura, Quaternary tectonic and recent seismic crustal movements in the Arauco Peninsula and its environs, central Chile, Geogr. Rep. 8, pp. 1-49, Tokyo Metrop. Univ., Tokyo, 1973.

Kanamori, H., and D. L. Anderson, Theoretical basis of some empirical relations in seismology, Bull. Seismol. Soc. Amer., 65, 10731095, 1975.

Karig, D. E., and J. Mammerickx, Tectonic framework of the New Hebrides island arc, Mar. Geol., 12, 187-205, 1972.

Luyendyk, B., W. B. Bryan, and P. A. Jezek, Shallow structure of the New Hebrides island arc, Geol. Soc. Amer. Bull., 85, 1287-1300, 1974.

Macfarlane, A., Geology of South Santo, scale 1: 100,000, New Hebrides Geological Survey sheet 4, Geol. 1181, Brit. Dir. of Overseas Surv., 1977.

Mallick, D. I. J., Some petrological and structural variations in the New Hebrides, in The Western Pacific: Islands Arcs, Marginal Seas, Geochemistry, edited by P. J. Coleman, pp. 193-211, Nedlands University, Western Australia Press, Perth, 1973.

Mallick, D. I. J., and D. Greenbaum, Geology of Southern Santo, regional report, 84 pp., New Hebrides Geol. Surv., Vila, 1977.

Mammerickx, J., T. E. Chase, S. M. Smith, and I. L. Taylor, Bathymetry of the South Pacific, map, Scripps Inst. of Oceanogr., La Jolla, Calif., 1971.

Matsuda, T., Y. Ota, M. Ando, and N. Yonekura, Fault mechanisms and recurrence time of major earthquakes in southern Kanto district, Japan, as deduced from coastal terrace data, Geol. Soc. Amer. Bull., 89, 1610-1618, 1978.

Mesolella, K. J., R. K. Matthews, W. S. Broecker, and D. L. Thurber, The astronomical theory of climatic change, Barbados data, $J$. Geol., 77, 250-274, 1969.

Mitchell, A. H. G., The geology of south Malekula, Reg. Rep. 3, 42 pp., New Hebrides Geol. Surv., Vila, 1966.

Mitchell, A. H. G., Raised reef-capped terraces and Plio-Pleistocene sea level changes, north Malekula, New Hebrides, J. Geol., 76, 5667, 1968.

Mitchell, A. H. G., Geology of north Malekula, regional report, 56 pp., New Hebrides Geol. Surv., Vila, 1971.

Mitchell, A. H. G., and A. J. Warden, Geological evolution of the New Hebrides island arc, J. Geol. Soc. London, 127, 501-529, 1971.

Neef, G., and H. H. Veeh, Uranium series ages and late Quaternary uplift in the New Hebrides, Nature, 269, 682-683, 1977.

Ota, Y., Deformed shorelines and late Quaternary crustal movements in Japan, Mem. Geol. Soc. Jap., 2, 15-24, 1968.

Pascal, G., B. L. Isacks, M. Barazangi, and J. Dubois, Precise relocations of earthquakes and seismotectonics of the New Hebrides island arc, J. Geophys. Res., 83, 4957-4973, 1978.

Plafker, G., Tectonics of the March, 1964 Alaska earthquake, U.S. Geol. Surv. Prof. Pap. 543-I, 74 pp., 1969.

Plafker, G., Alaskan earthquake of 1964, and Chilean earthquake of 1960: Implications for arc tectonics, J. Geophys. Res., 77, 901-925, 1972.

Plafker, G., and M. Rubin, Uplift history and earthquake recurrence as deduced from marine terraces on Middleton Island, Alaska, Proceedings of Conference VI: Methodology for Identifying Seismic Gaps and Soon-to-Break Gaps, Open File Rep. 78-943, pp. 687-721, U.S. Geol. Surv., Reston, Va., 1978.

Ravenne, C., G. Pascal, J. Dubois, F. Dugas, and L. Montadert, Model of a young intraoceanic arc: The New Hebrides island arc, report, pp. 63-78, Editions Technips, Paris, 1977. 
Robinson, G. P., The geology of north Santo, Reg. Rep. 2, 77 pp., New Hebrides Geol. Surv., Vila, 1969.

Savage, J. C., and L. M. Hastie, Surface deformation associated with dip-slip faulting, $J$. Geophys. Res., 71, 4897-4904, 1966.

Taylor, F. W., R. G. Fairbanks, C. Jouannic, and A. L. Bloom, Sclerochronology: A new method for absolute dating of paleoseismic uplift (abstract), Eos Trans $A G U, 60,400,1979$.

U.S. Coast and Geodetic Survey, Tide Tables, Central and Western Pacific Ocean and Indian Ocean, p. 386, Washington, D. C., 1965.

Yonekura, N., A review of seismic crustal deformations in and near Japan, Bull. Dep. Geogr. Univ. Tokyo, 4, 17-50, 1972.
Yonekura, N., Quaternary tectonic movements in the outer arc of southwest Japan with special reference to seismic crustal deformations, Bull. Dep. Geogr. Univ. Tokyo, 7, 19-71, 1975.

Yoshikawa, T., On the relations between Quaternary tectonic movement and seismic crustal deformation in Japan, Bull. Dep. Geogr. Univ. Tokyo, 2, 1-24, 1970.

(Received July 18, 1979; accepted November 7, 1979.) 